\title{
PI3K-AKT-mTOR and NFאB Pathways in Ovarian Cancer: Implications for Targeted Therapeutics
}

\author{
Alia Ghoneum ${ }^{1}$ and Neveen Said ${ }^{2, *(1)}$ \\ 1 Departments of Cancer Biology, Wake Forest University School of Medicine, Winston Salem, NC 27157, USA \\ 2 Departments of Cancer Biology, Pathology, and Urology, Wake Forest University School of Medicine, \\ Wake Forest Baptist Comprehensive Cancer Center, Winston Salem, NC 27157, USA \\ * Correspondence: nsaid@wakehealth.edu; Tel.: +01-336-718-9980
}

Received: 13 May 2019; Accepted: 30 June 2019; Published: 5 July 2019

\begin{abstract}
Ovarian cancer is the most lethal gynecologic malignancy in the United States, with an estimated 22,530 new cases and 13,980 deaths in 2019. Recent studies have indicated that the phosphoinositol 3 kinase (PI3K)/protein kinase B (AKT)/mammalian target of rapamycin (mTOR), as well as the nuclear factor- $\mathrm{k}$ light chain enhancer of activated B cells (NFkB) pathways are highly mutated and/or hyper-activated in a majority of ovarian cancer patients, and are associated with advanced grade and stage disease and poor prognosis. In this review, we will investigate $\mathrm{PI} 3 \mathrm{~K} / \mathrm{AKT} / \mathrm{mTOR}$ and their interconnection with NFKB pathway in ovarian cancer cells.
\end{abstract}

Keywords: PI3K-AKT-mTOR; NFkB; ovarian cancer; therapy

\section{Introduction}

Ovarian cancer $(\mathrm{OvCa})$ is the fifth most common type of cancer and the primary cause of gynecological cancer death in the United States [1]. At least $70 \%$ of patients are diagnosed at advanced stages with poor survival rates [2]. Despite aggressive debulking surgeries and adjuvant or neoadjuvant chemotherapy, recurrence is encountered in $70-80 \%$ of patients with poor prognosis and high mortality. In addition, there are limited second line treatment options for resistant or recurrent disease [2-4]. Therefore, there is an unmet need to understand the most frequently altered pathways that promote disease progression, recurrence, and chemoresistance.

The Cancer Genome Altas (TCGA) data revealed the hyperactivation of phosphoinositol 3 kinase (PI3K)/protein kinase B (AKT)/mammalian target of rapamycin (mTOR) (PI3K/AKT/mTOR) pathway in nearly $60 \%$ of patients with OvCa [1]. This pathway plays significant multifaceted roles in cancer cell growth, survival, metabolic programing, autophagy, transcription regulation, and angiogenesis [5-7]. Patients with high-grade serous cancer (HGSC) have several activating mutations with increased DNA copy numbers of $\mathrm{p} 110 \alpha$ (PIK3CA) and $\mathrm{p} 110 \beta$ (PIK3CB) subunits of PI3K $[6,8,9]$. Other subunits with mutations in OvCa include: PI3K p85 (PIK3R1) [10,11], AKT1 [12], AKT2 [13], PTEN [14], INPP4B [15], and MTOR [16]. Moreover, the mutation profile of serous ovarian cystadenocarcinoma, generated from cBioPortal for Cancer Genomics (http://www.cbioportal.org/), indicates that several key players in the $\mathrm{PI} 3 \mathrm{~K} / \mathrm{AKT} / \mathrm{mTOR} / \mathrm{NF} \kappa \mathrm{B}$ pathway are hyperactivated (Figure 1). 


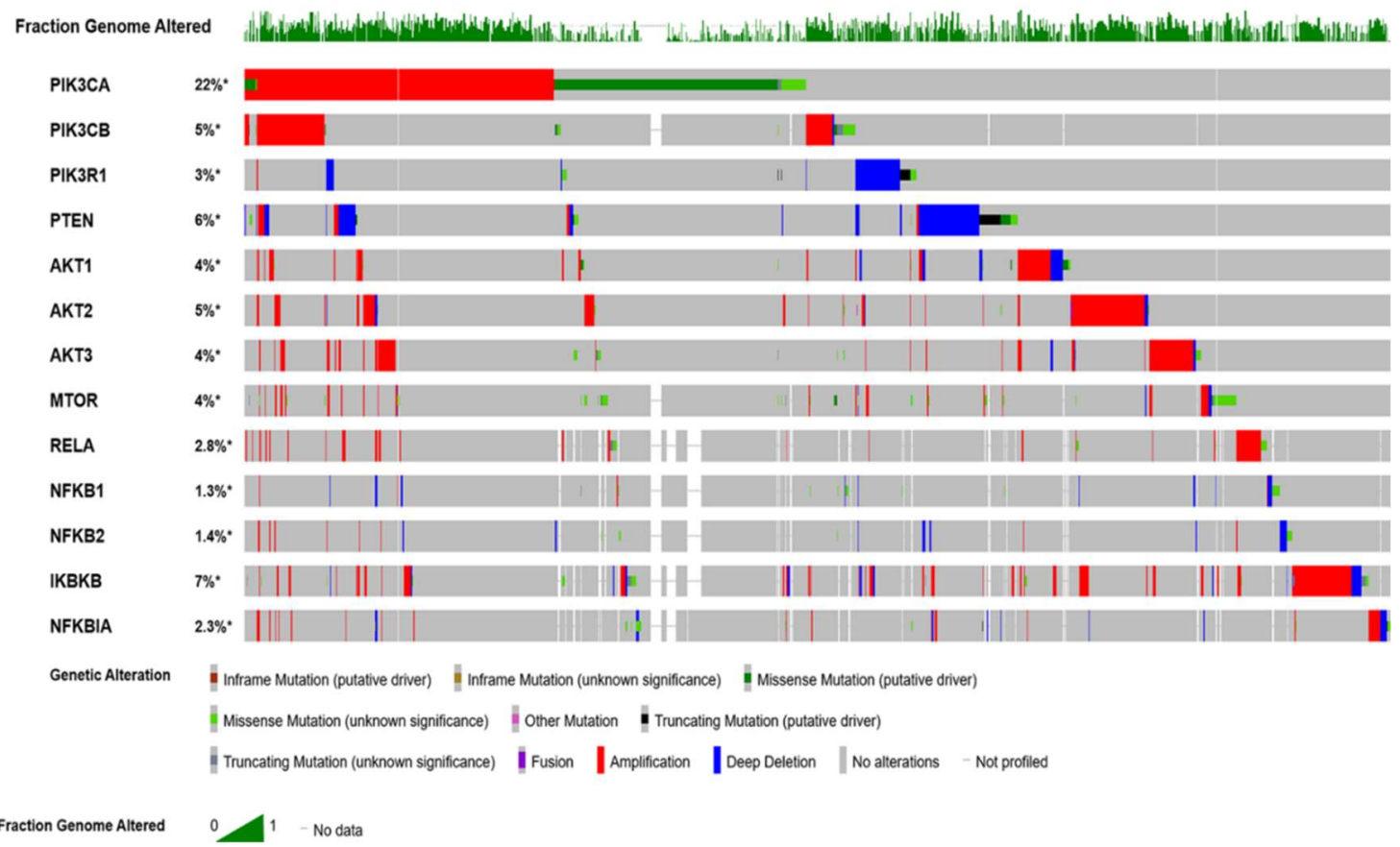

Figure 1. Oncoprint mutation profile of ovarian cancer data curated from The Cancer Genome Atlas (TCGA) datasets. Profile was generated from datasets in cBioPortal (http://www.cbioportal.org) for Cancer Genomics.

\section{Phosphoinositol 3 Kinase (PI3K)}

\subsection{Structural Overview}

Phosphoinositol 3 kinase (PI3K) defines a class of lipid kinases that have the ability to phosphorylate the inositol ring 3'-OH group in inositol phospholipids and hence produce phosphatidylinositol $(3,4,5)$-trisphosphate (PIP3) [17]. The importance of PI3K in signaling is tied to its highly regulated structure. PI3K comprises a family of enzymes divided into: Class I PI3K, which includes catalytic and regulatory subunits. Class IA PI3K includes three isomers $(\alpha, \beta, \delta)$, all of which are activated through receptor tyrosine kinases (RTKs). Class IB includes the group $(\gamma)$, which is activated via G protein coupled receptors (GPCR) [6,18]. The functions of this family of enzymes are as diverse as their structural derivatives. $\mathrm{P} 110 \alpha$ is a driver of angiogenesis, while $\mathrm{p} 110 \beta, \delta$, and $\gamma$ contribute to inflammatory responses. Moreover, p110 and mTOR play a role in B cell survival during adaptive immunity [18]. Due to its ability to affect several downstream effectors, PI3K Class IA is composed of a regulatory subunit p85 along with the catalytic PI3K $110 \alpha$ subunit [19]. Class II PI3K is divided into three subtypes-PI3KC2 $\alpha, \mathrm{PI} 3 \mathrm{KC} 2 \beta$, and PI3KC2 $\gamma$-all of which are catalytic subunits. While both PI3KC $2 \alpha$ and PI3KC2 $\beta$ have an N-terminal with a clathrin binding region, PI3KC $2 \alpha$ inhibits kinase activity and is implicated in clathrin-mediated endocytosis [20]. The N-terminal of PI3KC $2 \beta$ binds to the scaffold protein intersectin, which is involved in PtdIns(3)P synthesis [21]. Class III PI3K involves two subunits: vacuolar protein sorting 34 (Vps34), the catalytic subunit, and vacuolar protein sorting 15 (Vps15), the regulatory subunit. Vps15 works with Rab5 guanosine triphosphatase (GTPase) to coordinate the activity of Vps34 in endosomal maturation [22].

\subsubsection{Interactions of PI3K with Upstream Regulators}

Class IA and IB PI3K are activated when an extracellular growth factor or agonist has bound to their cognate receptor tyrosine kinases (RTKs) or to the G-protein coupled receptor (GPCR), respectively [6]. This causes phosphorylation and activation of the regulatory p85 subunit of PI3K followed by Ras activating the catalytic p $110 \alpha$ subunit. The activated PI3K heterodimer (PI3K-110 $\alpha$ and 
p85) leads to the conversion of phosphatidylinositol 4,5 bisphosphate (PIP2) to phosphatidylinositol (3,4,5)-trisphosphate (PIP3) [7]. PI3K is also involved in the extracellular matrix (ECM)-integrin-focal adhesion kinase (FAK) and/or integrin-like kinase (ILK) signaling pathway, which is integral for several cellular functions including cellular adhesion, cell cycle progression, cell migration, and invasion [23]. Activated integrins stimulate FAK, a cytoplasmic tyrosine kinase, which in turn activates PI3K [23]; in contrast, ILK is downstream of PI3K and uses the PIP3 generated to activate downstream targets such as AKT and glycogen synthase kinase 3 beta (GSK3 $\beta$ ) [24] (Figure 2).

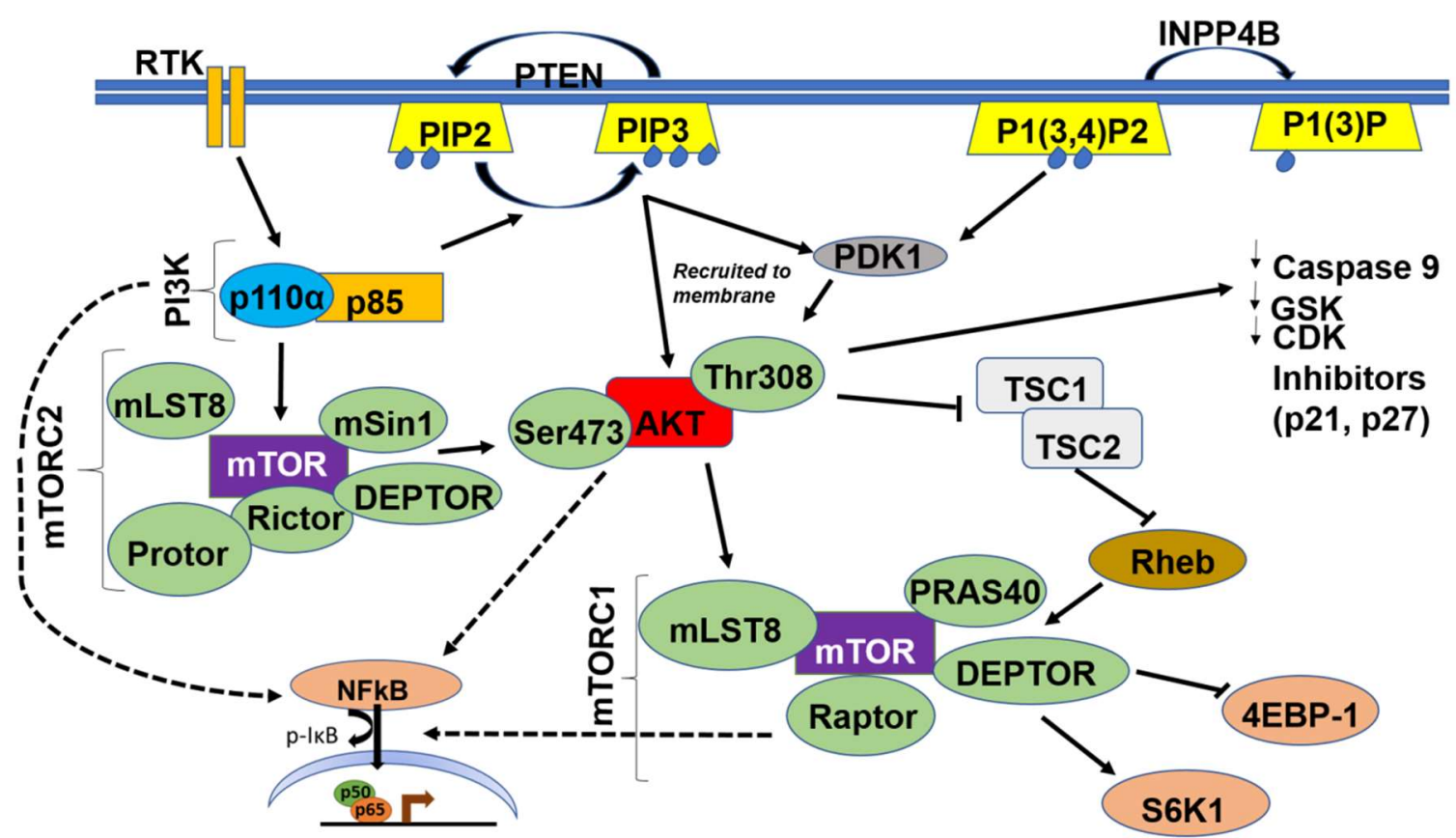

Figure 2. Schematic illustration of the PI3K/AKT/mTOR/NFkB Pathway. Dashed arrows indicate indirect activation of nuclear factor- $\mathrm{K}$ light chain enhancer of activated B cells (NFKB) by PI3K, AKT and $\mathrm{mTOR}$.

\subsubsection{Interactions of PI3K with Downstream Effectors}

PI3K triggers the activation of a wide range of downstream effectors via a pleckstrin homology $(\mathrm{PH})$ domain [25]. Protein kinase B (PKB), also known as AKT, is the main effector of PI3K, and serves as a pivotal serine/threonine kinase with multiple downstream targets. Other effectors include kinases, such as Bruton's tyrosine kinase (BTK), which is important for B-lymphocyte development and differentiation [26]. Effectors also include adaptors, such as GRB-associated binding protein (GAB1/2), tandem PH domain protein 1 (TAPP1), and dual adaptor for phosphotyrosine/3 phosphotyrosine (DAPP), all of which are important for downstream signaling responsible for survival, proliferation, and metastasis. Specific GTPase-activating proteins (GAPs) and guanine nucleotide exchange factors (GEFs) convert guanosine diphosphate (GDP) to GTP which are critical in a cornucopia of cellular processes including cell cycle progression, survival, actin polymerization, cellular polarization, metastasis, and nuclear transport [27-29]. PI3K directly activates downstream AKT by docking it to the cellular membrane, and indirectly activates AKT via mammalian target of rapamycin complex 2 (mTORC2) and phosphoinositide-dependent kinase-1 (PDK1), which in turn phosphorylate AKT at the serine 473 and threonine 308 sites, respectively [5,6,30]. 


\subsubsection{The Importance of PI3K $110 \alpha$ in OvCa}

In HGSC, PI3K p $110 \alpha$ is the most hyper-activated subunit within the PI3K pathway, being altered in nearly $70 \%$ of cases [5,31]. Studies have found that mutations in the gene encoding PI3K p110 $\alpha$, PIK3CA, are found in nearly $33 \%$ of clear-cell carcinoma cases, with the region of $3 \mathrm{q} 26$ having increased copy numbers in about 7 out of 9 established OvCa lines [32,33]. PIK3CA-activating mutations occur in $20 \%$ of endometrioid and clear-cell carcinomas [34]. TCGA data revealed activating mutations and amplifications of PIK3CA in 18-28\% of cases of serous cystadenocarcinoma, with enrichment of the signature of activated PI3K in a majority of cases irrespective of the subtype [31]. In addition, multivariate survival analysis revealed that PI3K protein expression scores were associated with poor survival in advanced HGSC; in contrast, in univariate analysis, no significant correlation between PI3K protein expression and survival was found [35]. Consistently, data from the Cancer Cell Line Encyclopedia (CCLE) and Domcke et al. [36] revealed activating mutations and amplifications in PIK3CA in serous, clear-cell, mucinous, and mixed subtype OvCa cell lines, including cell lines that have been extensively used in preclinical models of OvCa (Table 1). The increased activation of PI3K in OvCa and its role as a hub for several cancer-promoting pathways, explain its many implications in cancer progression including oncogenic transformation, cell proliferation, adhesion, and apoptosis, as well as multiple metabolic pathways [5,7,37-39]. PI3K is activated by the over-expressed/hyper-activated receptor tyrosine kinases, such as epidermal growth factor receptors (EGFRs), vascular endothelial growth factor receptors (VEGFRs), and platelet-derived growth factor receptors (PDGFRs) [40], as well as receptors for lysophosphatidic acid (LPA) [41], bioactive lipids, cytokines/ chemokines [42], prostaglandin E2 (PGE2) [43], endothelin [44], and angiotensinogen [45-48], inducing a plethora of pro-survival, pro-invasive, and pro-inflammatory mediators that further promote OvCa proliferation and invasiveness [41]. Thus, activation of PI3K was shown to be inhibited by RTK and FAK inhibitors, as well as cytokine/chemokine/receptors inhibitors leading to inhibition of OvCa cells migration and invasion through inhibiting downstream PI3K-AKT signaling [49]. 
Table 1. Summary of mutations in the PI3K-AKT pathway in 13 OvCa cell lines collected from Cancer Cell Line Encyclopedia (CCLE), https://oncokb.org, and [36].

\begin{tabular}{|c|c|c|c|c|}
\hline Cell Line & Annotation & PI3K & PTEN & AKT \\
\hline A2780 & Unlikely HGSC/not-specified & PIK3CA Missense p.E365K & Deletion & AKT3 Gain \\
\hline CAOV3 & Likely HGSC/adenocarcinoma & PIK3CA amplification & Gain & AKT1/2 Gain \\
\hline IGROV1 & Mixed subtype/hypermutated & $\begin{array}{c}\text { PIK3CA Missense/non-stop p.R38C \& } \\
\text { p.1069W } \\
\text { PIK3CB p.A686V }\end{array}$ & p.Y155C Loss of function & \\
\hline MCAS & Mucinous cystadenocarcinoma & PIK3CA Missense p.H1047R & Gain & \\
\hline OVMIU & Not-specified & PIK3CA Missense p.H1047R & & \\
\hline OVMANA & Clear-cell & PIK3CA Missense p.E545V & & \\
\hline OVISE & Clear-cell & PIK3CA Missense p.C420R & & AKT2 Gain \\
\hline OC314 & Serous & PIK3CA Missense p.R108H & & \\
\hline OC316 & Low-differentiated adenocarcinoma & $\begin{array}{l}\text { PIK3CA Missense p.R108H } \\
\text { PIK3CG p.T309M \& p.R542W }\end{array}$ & Heterozygous loss & AKT1 Gain \\
\hline $\mathrm{EFO} 27$ & Mucinous & PIK3CA Missense p.H510N & & \\
\hline COV318 & Serous/non-specified? & $\begin{array}{c}\text { PIK3CA Gain/amplification? } \\
\text { PIK3CB Missense p.W676R \& p.V260I }\end{array}$ & & AKT1/2/3 Gain \\
\hline OVCAR3 & $\begin{array}{l}\text { Poorly differentiated papillary } \\
\text { adenocarcinoma/possibly HGSC }\end{array}$ & $\begin{array}{c}\text { PIK3CA AMP } \\
\text { PIK3R1 splice variant c.e14-1 (likely loss } \\
\text { of function) }\end{array}$ & & AKT2 amplification/Gain \\
\hline SKOV3 & $\begin{array}{l}\text { Moderately well-differentiated } \\
\text { adenocarcinoma/mixed subtype }\end{array}$ & PIK3CA Missense p.H1047R & Heterozygous loss & \\
\hline TOV21G & $\begin{array}{l}\text { Clear-cell } \\
\text { adenocarcinoma/hyper-mutated }\end{array}$ & PIK3CA Missense p.H1047Y & Gain & \\
\hline OAW42 & Non-specified & PIK3CA Missense p.H1047L & Heterozygous loss & AKT2 Gain \\
\hline FUOV1 & Serous & & & AKT1/2 Gain \\
\hline
\end{tabular}




\subsubsection{Correlation of PI3K Mutations in OvCa with Standard of Care Therapy}

The vast majority of HGSC patients will experience recurrence with platinum or taxane resistance [50]. Several preclinical studies using cell-based assays indicated that chemo-resistance, specifically to taxanes, is highly correlated with PI3K activation and hyperactivating mutations [51,52]. In OVCAR3, PIK3CA is amplified (six copies) and PIK3R1 contains a splice site on chromosome 5.

In SKOV3, PIK3CA contains a missense mutation on chromosome 3. In CaOv3, PIK3CA is amplified with 6.7 copies, and in IGROV1, both PIK3CA and PIK3CB contain missense mutations on chromosome 3 (Table 1). Importantly, the PIK3CA mutation most commonly detected in human cancers include OvCa patients' specimens and OvCa cell lines is the H1047R mutation [53]. Further analysis of several human OvCa cell lines revealed that PIK3CA mutations coexisted with KRAS and/or PTEN mutations indicating the requirement of a secondary defect in a co-regulator of PI3K activity for mutant PIK3CA to promote transformation. This was further supported by conditional activation of this mutation in the mouse ovary, showing that $P i k 3 c a^{\mathrm{H} 1047 \mathrm{R}}$ alone was capable of inducing premalignant hyperplasia with no tumors of the ovarian surface epithelium. A concomitant $P i k 3 c a^{\mathrm{H} 1047 \mathrm{R}}$ mutation plus PTEN deletion in the mouse ovary led to the development of ovarian serous adenocarcinomas and granulosa cell tumors. Both mutational events were required for early, robust Akt activation [53]. Pharmacological inhibition of PI3K/mTOR in these mice delayed tumor growth and prolonged survival. Several studies have shown that the rate of mutations in the PI3K pathway, especially in p-AKT and p-p70S6K, including missense mutations and amplifications, is correlated with higher rates of chemoresistance $[52,54]$. Chemo-sensitization could be achieved via downregulation of PI3K and/or its downstream effectors AKT and mTORC1 [55-57]. Consistently, in cell lines and 3D OvCa culture models, cisplatin resistance was overcome via upregulation of the tumor suppressor phosphatase and tensin homolog (PTEN) and downregulation of PI3K p110 $\alpha$, as well as the phosphorylated form of AKT (pAKT) [58-61]. Importantly, TCGA data analysis (http://kmplot.com/analysis) [62] revealed that the high expression of transcripts encoding PI3K subunits are correlated with poor patient survival (Figure 3). Moreover, there is a significant tendency of co-occurrence of PI3K/AKT/MTOR/NFkB mutations and alteration in OvCa (Table 2). While significant evidence exists that implicate mutations in PI3K/AKT/mTOR/NFKB in OvCa aggressiveness, it is important to note that the genomic architecture of OvCa is heterogeneous and multifaceted. PIK3CA mutations are considered driver mutations that provide transformative and positive advantages for cancer cells growing mainly in clear-cell, endometroid, and mucinous OvCa [63]. An integrated study of multi-omics data collected from the TCGA indicated that in HGSC, driver genes included well-known genes such as CCNE1 (cyclin E1), CDKN2A (p16), KRAS (Kirsten rat sarcoma), PTEN, and RB1 (retinoblastoma protein 1), as well as more obscure genes such as EVI2A (ecotropic viral integration site 2A), C1orf114 (coiled-coil domain containing 181), and LCP2 (lymphocyte cytosolic protein 2) [64,65]. Thus, in HGSC, PTEN inactivation is considered an activating factor for PIK3CA.

Table 2. Summary of the tendencies of PI3K/AKT/MTOR/NFKB mutations to co-occur in OvCa (curated from http://www.cbioportal.org).

\begin{tabular}{cccccc}
\hline A & B & Both & Log2 Odds Ratio & $p$-Value & $q$-Value \\
\hline PIK3CA & PIK3CB & 117 & 2.813 & $<0.001$ & $<0.001$ \\
PIK3CA & AKT3 & 60 & 1.272 & $<0.001$ & $<0.001$ \\
PIK3CB & MTOR & 21 & 2.009 & $<0.001$ & $<0.001$ \\
PTEN & AKT1 & 23 & 1.814 & $<0.001$ & $<0.001$ \\
AKT1 & IKBKB & 23 & 1.659 & $<0.001$ & $<0.001$ \\
PIK3CA & PTEN & 75 & 0.918 & $<0.001$ & $<0.001$ \\
PIK3R1 & MTOR & 14 & 2.132 & $<0.001$ & $<0.001$ \\
PIK3CA & RELA & 37 & 1.343 & $<0.001$ & $<0.001$ \\
PIK3CA & MTOR & 47 & 1.109 & $<0.001$ & $<0.001$ \\
AKT3 & MTOR & 16 & 1.808 & $<0.001$ & $<0.001$ \\
AKT2 & AKT3 & 20 & 1.576 & $<0.001$ & $<0.001$ \\
PTEN & NFKBIA & 15 & 1.875 & $<0.001$ & $<0.001$ \\
\hline
\end{tabular}


Table 2. Cont.

\begin{tabular}{cccccc}
\hline A & B & Both & Log2 Odds Ratio & $p$-Value & $q$-Value \\
\hline PIK3R1 & IKBKB & 19 & 1.607 & $<0.001$ & $<0.001$ \\
AKT1 & NFKB2 & 8 & 2.582 & $<0.001$ & $<0.001$ \\
PTEN & MTOR & 19 & 1.484 & $<0.001$ & 0.001 \\
AKT2 & IKBKB & 26 & 1.247 & $<0.001$ & 0.001 \\
IKBKB & NFKBIA & 14 & 1.598 & $<0.001$ & 0.004 \\
PIK3CB & NFKB1 & 8 & 2.15 & 0.001 & 0.005 \\
PIK3R1 & AKT1 & 11 & 1.679 & 0.002 & 0.006 \\
PTEN & NFKB2 & 9 & 1.929 & 0.002 & 0.006 \\
PIK3CB & NFKB2 & 8 & 2.034 & 0.002 & 0.007 \\
PIK3CA & AKT2 & 57 & 0.707 & 0.002 & 0.008 \\
AKT3 & NFKB2 & 7 & 2.08 & 0.003 & 0.009 \\
MTOR & NFKB1 & 6 & 2.205 & 0.004 & 0.011 \\
PIK3CB & AKT1 & 14 & 1.248 & 0.005 & 0.016 \\
PIK3CB & NFKBIA & 10 & 1.474 & 0.006 & 0.019 \\
AKT2 & NFKBIA & 10 & 1.449 & 0.007 & 0.021 \\
PIK3CA & NFKBIA & 27 & 0.897 & 0.008 & 0.023 \\
AKT3 & NFKB1 & 6 & 1.922 & 0.008 & 0.023 \\
PIK3CB & AKT2 & 17 & 0.982 & 0.012 & 0.03 \\
AKT2 & MTOR & 13 & 1.12 & 0.013 & 0.031 \\
PIK3CA & $I K B K B$ & 68 & 0.501 & 0.013 & 0.031 \\
NFKB1 & NFKBIA & 4 & 2.245 & 0.014 & 0.032 \\
RELA & NFKBIA & 6 & 1.728 & 0.014 & 0.032 \\
RELA & IKBKB & 12 & 1.106 & 0.018 & 0.04 \\
AKT1 & AKT3 & 11 & 1.129 & 0.02 & 0.043 \\
RELA & NFKB1 & 4 & 2.051 & 0.021 & 0.045 \\
RELA & NFKB2 & 4 & 1.945 & 0.026 & 0.054 \\
PIK3CA & NFKB2 & 16 & 0.96 & 0.027 & 0.054 \\
PIK3CB & PTEN & 18 & 0.772 & 0.032 & 0.062 \\
AKT3 & RELA & 8 & 1.176 & 0.036 & 0.068 \\
\hline
\end{tabular}


Figure 3. Kaplan-Meier (KM) plots indicating the correlation of PI3K/AKT/mTOR/NFkB expression with patient survival. ${ }^{*} p<0.05$. KM curves were generated via a KM plot using only JetSet best probe set with analysis restricted to: Serous and Stages $3+4$. 


\section{Protein Kinase B PKB/AKT}

\subsection{Structural Overview}

The AKT/PKB family encompasses a group of serine threonine kinases, which are cAMP- and cGMP-dependent [66]. The three AKT isoforms-AKT1 (PKB $\alpha)$, AKT2 (PKB $\beta)$, and AKT3 (PKB $\gamma)$-all contain a conserved N-terminal plekstrin homology $(\mathrm{PH})$ domain, a central kinase domain, and a C-terminal regulatory domain that holds a hydrophobic region. The PH domain binds to the PIP3 at the inner side of the cell membrane and allows for the phosphorylation and activation of AKT [17,67]. The serine and threonine phosphorylation sites vary in each isoform, giving each its own unique role. AKT1 is involved in cellular growth, angiogenesis, and tumor cell invasiveness. AKT2 mediates glucose homeostasis and AKT3 aids in neuronal development and processing. AKT1 and AKT3 together are involved in embryonic development, while AKT1 and AKT2 act to regulate adipogenesis, as well as skin, bone, brain, and muscle development [68-74].

\subsubsection{Upstream AKT Activation}

AKT is the main kinase that integrates upstream signals from PI3K and mammalian target of rapamycin complex 2 (mTORC2) with downstream signals to mTORC1 (Figure 2). These signals play a pivotal role in the phosphorylation of downstream substrates and dictate several cellular activities including survival, proliferation, and migration $[38,66,70]$. AKT is activated via several mechanisms such as recruitment to the membrane by PIP3, phosphorylation at the threonine 308 site by PDK1, and phosphorylation at the serine 473 site by mTORC2. Activated phospho-AKT phosphorylates and activates mTORC1 at serine 248, either directly or indirectly, by inhibiting tuberous sclerosis complex 1 and $2(\mathrm{TSC} 1 / 2)[67,75-77]$.

\subsubsection{Downstream Effectors of AKT}

AKT affects broad downstream targets that induce proliferation and cell cycle progression, apoptosis, and protein synthesis and cell growth [67]. The role of AKT in cell proliferation is mediated via the inhibition of several substrates. AKT phosphorylates GSK-3 $\alpha$ at serine 21 and GSK-3 $\beta$ at serine 9, which inhibit GSK-3 kinase activity, thereby halting glycogen synthase, the key enzyme in glycogenesis, which is an important pathway for tumor cell metabolism [78,79]. In turn, GSK-3 phosphorylates several targets, including beta catenin, cyclin D1, and Myc, leading to their polyubiquitination and proteasomal degradation [67]. AKT inhibits Forkhead Box O4 (FOXO4), a transcription factor that induces cyclin D kinase (CDK) inhibitors, p21 (CIP1), and p27 (KIP1) [67]. Furthermore, AKT phosphorylates CDK inhibitors p21 and p27, hence mitigating their inhibitory effect on cyclins D and E, conferring AKT's integral role in the regulation of cell cycle progression $[66,67]$.

With regard to its anti-apoptotic effects, AKT inhibits several downstream signaling molecules, including caspase 9, while phosphorylating serine 136 of the $\mathrm{Bcl} 2$ associated death protein (BAD), leading to the dissociation of Bcl-2 on the mitochondrial membrane and inhibition of apoptosis [66,80]. Moreover, AKT phosphorylates the Forkhead family of transcription factors (FOXO), causing them to bind to 14-3-3 proteins, thus preventing the nuclear translocation of FOXO-1 and FOXO-3, as well as preventing apoptosis in cancer cells [81]. AKT also activates nuclear factor kappa-light-chain-enhancer of activated B cells (NFKB) and cAMP responsive element binding protein (CREB), as well as anti-apoptotic genes such as X-linked inhibitor of apoptosis (XIAP), survivin, and inhibitor of nuclear transcription factor $\mathrm{\kappa B}(\mathrm{IkB})$ kinase [9]. In addition, in vitro studies demonstrated that constitutively active AKT allows for activation and nuclear translocation of mouse double minute 2 homolog (MDM2), an E3 ubiquitin protein ligase that degrades p53, reducing cellular p53 levels, and thereby reduces p53 transcriptional activity $[82,83]$. Moreover, AKT promotes protein synthesis and cell growth by inhibiting TSC2, a tumor suppressor that is responsible for inhibiting cell growth in various cancer types, and 4E-binding protein 1 (4E-BP1), a regulator of mRNA translation and cellular proliferation $[7,9,67,84,85]$. 


\subsubsection{Inhibition of AKT.}

AKT is inhibited by tumor suppressors including PTEN and inositol polyphosphate 4-phosphatase type II (INPP4B). PTEN dephosphorylates PIP3 to produce PIP2, hence decreasing the downstream activation of phosphoinositide-dependent kinase-1 (PDK1) and phosphorylation of AKT $[67,86]$. It is important to note that the PTEN/PI3K/AKT pathway is not linear [87]. Transgenic mice with Pten deletion/mutation exhibited accelerated tumorigenesis and increased levels of activated AKT [88]. However, in Pten-deficient prostate cancer models, deletion of the $\mathrm{p} 110 \beta$, but not $\mathrm{p} 110 \alpha$, subunit of PI3K was able to inhibit tumorigenesis and AKT activation [89], implying the direct effect of p110ß-PI3K on AKT activation. These were also reported in patients with various neoplasms including OvCa, endometrial [90], esophageal cancers [91], and prostate cancers, as well as B-cell chronic lymphocytic and acute myeloid leukemia $[92,93]$. Another mechanism of inactivation of AKT is through INPP4B, which dephosphorylates and inactivates PI 3,4 bisphosphate (P13, 4P2), a direct activator of AKT, thereby obstructing AKT-induced downstream signaling. Loss of function mutations of INPP4B are highly prominent in OvCa [94] and have been correlated with increased ovarian and breast tumorigenicity in xenograft models and across patient samples [67,95-97].

\subsubsection{AKT in OvCa}

In OvCa, activated AKT causes growth deregulation and strong resistance to apoptotic stimuli, leading to uncontrolled tumor growth and cell invasion [7]. AKT is classified as an oncogene when there is a point mutation at the PH domain, and can be activated, independent of upstream PI3K signaling. Specifically, studies have indicated that AKT1 is mutated at E17K and Q79K sites, and AKT2 is amplified in about $40 \%$ of OvCa $[7,98]$. AKT overexpression in OvCa increases their susceptibility to platinum resistance [54]. Ectopic overexpression of AKT in OvCa cell lines increased their cisplatin resistance [99]. Cisplatin-resistant OvCa cell line A2780cis exhibited higher AKT expression levels than its cisplatin sensitive isotype [100]. Similarly, cell lines expressing higher levels of the activated AKT (phosphoAKT) were more resistant to paclitaxel [54,101]. Survival analysis of advanced stage HGSC (stages $3+4)$ in TCGA data using Kaplan-Meier (KM) plot (http://kmplot.com/analysis) [62] indicates that higher expression levels of AKT isoforms is associated with poor patient survival rates (Figure 3).

\section{Mammalian Target of Rapamycin (mTOR)}

\subsection{Structural Overview}

mTOR comprises two biochemically and functionally independent catalytic complexes, mTORC1 and mTORC2. The two complexes share two subunits, DEP domain containing mTOR-interacting protein (DEPTOR) and mammalian lethal with SEC18 protein 8 (mLSt8) (Figure 2). Subunits unique to mTORC1 are Raptor and protein rich AKT substrate 40 (PRAS40), and those unique to mTORC2 are protein observed with Rictor-1 (Protor), mammalian stress-activated protein kinase interacting protein 1 (mSin1), and Rictor [102-105]. Higher expression levels of MTOR correlated with poor survival rates (Figure 3). Moreover, several studies have demonstrated that along with AKT, mTOR is highly hyperactivated and mutated in OvCa, warranting the use of mTOR inhibitors as targeted therapies after standard of care therapies, and in several clinical trials (Table 3) $[76,77,106]$. 
Table 3. Current clinical trials targeting the PI3K/AKT/mTOR/NFkB pathway in OvCa.

\begin{tabular}{|c|c|c|c|}
\hline Drug & Target & Clinical Trial & NCT Trial \\
\hline CUDC-907 & PI3K/HDAC & Phase 1 & NCT02307240 \\
\hline Copanlisib & PI3K & Phase $1 b$ & NCT03586661 \\
\hline BKM120/BYL719 & PI3K & Phase 1 & NCT01623349 \\
\hline MK2206 & AKT & Phase 2 & NCT01283035 \\
\hline BKM120 + MEK162 & PI3K & Phase 1 & NCT01363232 \\
\hline AZD5363 & AKT & Phase 1 & NCT01226316 \\
\hline GSK2141795 & $\mathrm{AKT}$ & Phase 1 & NCT01266954 \\
\hline Triciribine (PTX-200) & AKT & Phase 1 & NCT01690468 \\
\hline Miransertib(ARQ 092) & $\mathrm{AKT}$ & Phase $1 \mathrm{~b}$ & NCT02476955 \\
\hline Perifosine & PI3K/ AKT & Phase 1 & NCT00431054 \\
\hline Sapanisertib & mTOR & Phase 2 & NCT02465060 \\
\hline Everolimus & mTOR & Phase 2 & NCT01149434 \\
\hline $\begin{array}{l}\text { Nanoparticle albumin-bound } \\
\text { rapamycin }\end{array}$ & mTOR & Phase 1 & NCT02646319 \\
\hline Sirolimus & mTOR & Phase 1 & NCT02833506 \\
\hline TAK228 & PI3K/ AKT/mTOR & Phase 2 & NCT03648489 \\
\hline MLN0128 & TORC $1 / 2$ & Phase 1 & NCT02142803 \\
\hline Temsirolimus & mTOR & Phase 2 & NCT02093598 \\
\hline AZD2014 & mTOR & Phase 1b & NCT02208375 \\
\hline IMX-110 & Stat3/NF-kB/poly-tyrosine kinase & Phase $1 / 2 a$ & NCT03382340 \\
\hline
\end{tabular}

\subsubsection{Upstream Activation of mTORC1}

Both mTOR complexes are implicated in the induction of angiogenesis, proliferation, and cellular survival [6,103]. For example, during the M-phase of the cell cycle, the active form of mTOR, phospho-mTOR, is expressed at high levels in ovarian granulosa cells, suggesting its instrumental role in cellular checkpoint regulation [107]. mTORC1 plays an important and complex role in nutrient delivery and cellular energy, acting as a cellular energy sensor through AMP-activated protein kinase (AMPK) [102,108]. Once energy levels in the cell decline, AMPK is activated, leading to a downregulation of energy-consuming processes like protein synthesis, and in turn, initiates energy-generating processes such as fatty acid oxidation [108,109]. In addition to the involvement of mTOR with AMPK and cell cycle checkpoints, there is extensive crosstalk between AKT and mTORC1. There are two mechanisms by which AKT activates mTOR. AKT can directly phosphorylate and activate mTORC1, and can indirectly inhibit TSC1/2, activating Ras homolog enriched in brain (RHEB), a GTP-binding protein that activates mTORC1 $[77,103]$. Moreover, AMPK has been shown to inhibit mTORC1 via two mechanisms, by phosphorylating and activating TSC2, or by phosphorylating RAPTOR and disrupting the mTORC1 complex configuration. Several studies have suggested that PI3K class III member, VPS34, has a regulatory interaction with mTORC1. The inhibitory effect of AMPK on Raptor and the effect of VPS34 on mTORC1 lead to downstream autophagy in malignant cells [102,110-112].

\subsubsection{Downstream Effectors of mTORC1}

Phospho-mTOR activates two downstream targets: the 4E-binding protein 1 (4E-BP1) and ribosomal protein $\mathrm{S} 6$ kinase (S6K). Upon stimulation, 4E-BP1 dissociates from eukaryotic translation initiation factor $4 \mathrm{E}$ (eIF4E), leading to the subsequent formation of the eIF4F complex and translation initiation [113]. 4EBP1 influences the metabolic components of the tumor microenvironment by regulating specific mRNA translational events [113-116]. Specifically, in aggressive cancers, 4E-BP1 functions as a hypoxia-inducible switch, allowing for translation of factors, such as VEGF, HIF1 $\alpha$, and $\mathrm{Bcl} 2$, and hence facilitating angiogenesis and anti-apoptotic cell growth $[85,117]$. Phosphorylated S6K is required for cell growth and G1 cell cycle progression [102,109]. The activated mTOR also causes selective translation of proteins involved in survival, including survivin, myeloid leukemia sequence 1 (McL1), and X-linked inhibitor of apoptosis (XIAP); angiogenic factors, such as vascular 
endothelial growth factor A (VEGF-A) and fibroblast growth factor 2 (FGF2); and DNA repair genes, such as breast cancer 1 (BRCA1), p53 binding protein 1 (53BP1), and H2A histone family member $\mathrm{X}$ $(\gamma \mathrm{H} 2 \mathrm{AX})[37,75-77]$.

\subsubsection{Upstream Regulators of mTORC2}

While the upstream regulators of mTORC1 have been established over several studies, regulators for mTORC2 are less clearly defined. Several hypotheses have been proposed to explain mTORC2 regulation. Liu et al. [118] proposed a model whereby stress-activated protein kinase (SAPK)-interacting protein 1 (SIN1) binds and inactivates mTORC2 enabling PIP3 to free mTORC2 from SIN1, and thus, allowing for AKT phosphorylation. A second model proposes a positive feedback mechanism between AKT and mTORC2 whereby AKT phosphorylates SIN1, leading to activation of mTORC2 kinase. mTORC2 then phosphorylates AKT, catalyzing the full activation of AKT [119]. The third hypothesis implies that the TSC complex (TSC1/2) physically associates with and activates mTORC2 in a GTPase-independent manner $[120,121]$. These hypotheses all suggest that upstream molecules exert a highly complex regulation of mTORC2 signaling.

\subsubsection{Downstream Effectors of mTORC2}

The Rictor-mTOR complex forms a hydrophobic motif kinase that phosphorylates and activates AKT on the ser473 [122]. While both Rictor and Sin1 act in conjunction with mTOR, they can also act independently of the mTORC2 complex [102]. Rictor can independently activate ILK, mysosin 1C (Myo1c), and cullin1 (CUL1); while Sin1 can activate c-Jun N-terminal kinase (JNK), Ras, and MAPK/ERK kinase kinase (MEKK2/3), suggesting that Rictor and Sin1 facilitate other cellular activities not dictated by mTORC2 [122-124].

\subsection{5. $\mathrm{mTOR}$ in $\mathrm{OvCa}$}

mTOR1 is activated in 55\% of epithelial OvCa and this hyper-activated mTOR is involved in cell growth, angiogenesis, and evasion of cell death $[31,37,125]$. Several studies have reported that nearly $41 \%$ and $26.4 \%$ of HGSC express the phosphorylated form of mTOR1 targets 4EBP1 and 70S6K, respectively, implying that mTORC1 activity is associated with a more aggressive phenotype and poor prognosis [126]. Consistently, analysis of TCGA data indicated that high expression of MTOR is associated with poor survival rates in patients with advanced stage (stage $3+4$ ) HGSC (Figure 3).

\section{5. $\mathrm{NF} \kappa \mathrm{B}$}

\subsection{Structural Overview}

Nuclear factor- $k$ light chain enhancer of activated B cells (NFkB) comprises a group of transcription factors that are divided into two classes: Class I, which include NFKB1 or p50/p105 (in which p50 is the processed product of the precursor, p105), and NFKB2 or p52/p100 (in which p52 is the processed product of p100). Class II includes RelA/p65, RelB, and c-Rel. All members have a Rel homology domain that includes the $\mathrm{N}$-terminal and $\mathrm{C}$-terminal domains positioned before the nuclear localization signal. In addition to the Rel homology region, members of Class II in particular, also carry a transactivation domain at the C-terminus $[127,128]$.

\subsubsection{Canonical Pathway}

The NFkB canonical pathway includes NFkB1 (a complex composed of the cleaved subunit p50), $\operatorname{IKB} \alpha$, and RelA/p65. IkB $\alpha$ is phosphorylated by the Inhibitor Of Nuclear Factor Kappa B Kinase (IKK) complex at two N-terminal sites: ser32 and er36 [129,130]. The IKK complex is composed of IKK $\alpha$, IKK $\beta$, and IKK $\gamma$ (NF-kappa-B essential modulator, NEMO). Upon phosphorylation of NFKB1, the $\mathrm{IKB} \alpha$ subunit undergoes ubiquitination and subsequent proteasomal degradation. This allows p50 and RelA to dimerize and translocate to the nucleus where they induce the transcription of genes 
involved in inflammation, cell growth, and apoptosis. Several factors, such as substrates for antigen receptors and cytokines, can trigger activation of the canonical pathway. In addition to p50 and RelA heterodimer, p50 and c-Rel can also dimerize and enter the nucleus to initiate downstream transcription of antiapoptotic genes, such as Bcl-xL, and genes involved in checkpoint inhibition of the cell cycle [131,132].

\subsubsection{Non-Canonical Pathway}

In this pathway, NFkB2 is composed of p100ANK/RDH and RelB. Activation of this pathway is achieved when inflammatory cytokines, TNF and IL1, bind to their cognate receptors and subsequently signal to NFKB inducing kinase (NIK) to activate the IKK complex [133]. In this case, the IKK complex is solely composed of IKK $\alpha$ dimers [134]. This IKK $\alpha$ homodimer phosphorylates two sites on NFKB2 at serine 866 and 870, leading to the degradation of p100 into p52 [132], dimerization of p52 and RelB subunits, and their translocation to the nucleus, where they induce the transcription of genes involved in immune function specifically of B cells [132].

\subsubsection{Regulation of NFKB}

In addition to the regulation of the canonical $\mathrm{NF} K \mathrm{~B}$ pathway by the IkB/IKK complex in the cytoplasm, this pathway is regulated at multiple levels involving heterodimerization, nuclear translocation, and even after p65RelA/p50 heterodimers translocate to the nucleus. In addition, acetyltransferases in the nucleus, specifically p300/CBP, are critical in the acetylation of RelA, mainly at lysines 218, 221, 310, and 314 [135]. Lysine acetylation of RelA influence NFKB DNA binding affinity and transcriptional activation $[135,136]$. IKB $\alpha$ acts as a post-induction repressor of NF-kappaB/Rel proteins $[137,138]$ as it contains ankyrin repeats that aid in its nuclear localization and attachment to the deacetylated form of p65/RelA, leading to the nuclear export of the NFkB [139]. Canonical NFKB activation can also be occur in an atypical manner by DNA damage and involves formation of a complex between Ataxia Telangiectasia Mutated (ATM), NEMO, and IKKs. RelA interacts through the Rel homology domain with Breast Cancer 1 (BRCA1) to enhance the transcriptional activation of $\mathrm{NF}_{K \mathrm{~B}}$ target genes. This process is dependent upon the phosphorylation of p65/RelA at serine 276, and BRCA1 (Really Interesting New Gene (RING) finger domain [140]. BRCA1 was identified as a regulator of NFKB (p65/p50) activation in response to DNA-damaging agents, etoposide and camptothecin [141]. BRCA1 activates NFKB by facilitating the p65-independent recruitment of the p50 onto the promoter of responsive genes. This activation of NFKB has been shown to contribute to chemoresistance through repression of BRCA1-induced apoptosis in response to DNA damage [141].

\subsubsection{PI3K-AKT-mTOR-NFkB Axis}

The reciprocal interactions between the multiple nodes of PI3K-AKT-mTOR and NFkB pathways have been highlighted in myriad physiologic and pathologic contexts. In silico analysis of PI3K-AKT-mTOR and NFkB expression, and correlation in OvCa TCGA samples using KM plot (http://kmplot.com/analysis) [62] and GEPIA web tools (http:/gepia.cancer-pku.cn/index.html) [2], revealed that they are not only associated with poor survival, but they also exhibited significant positive correlation at multiple nodes by both Pearson correlation, which determines the linear relationship between two continuous variables, used in combination with the Spearman correlation coefficient, which is chiefly based on ranked values for each variable (Figures 4-6). 

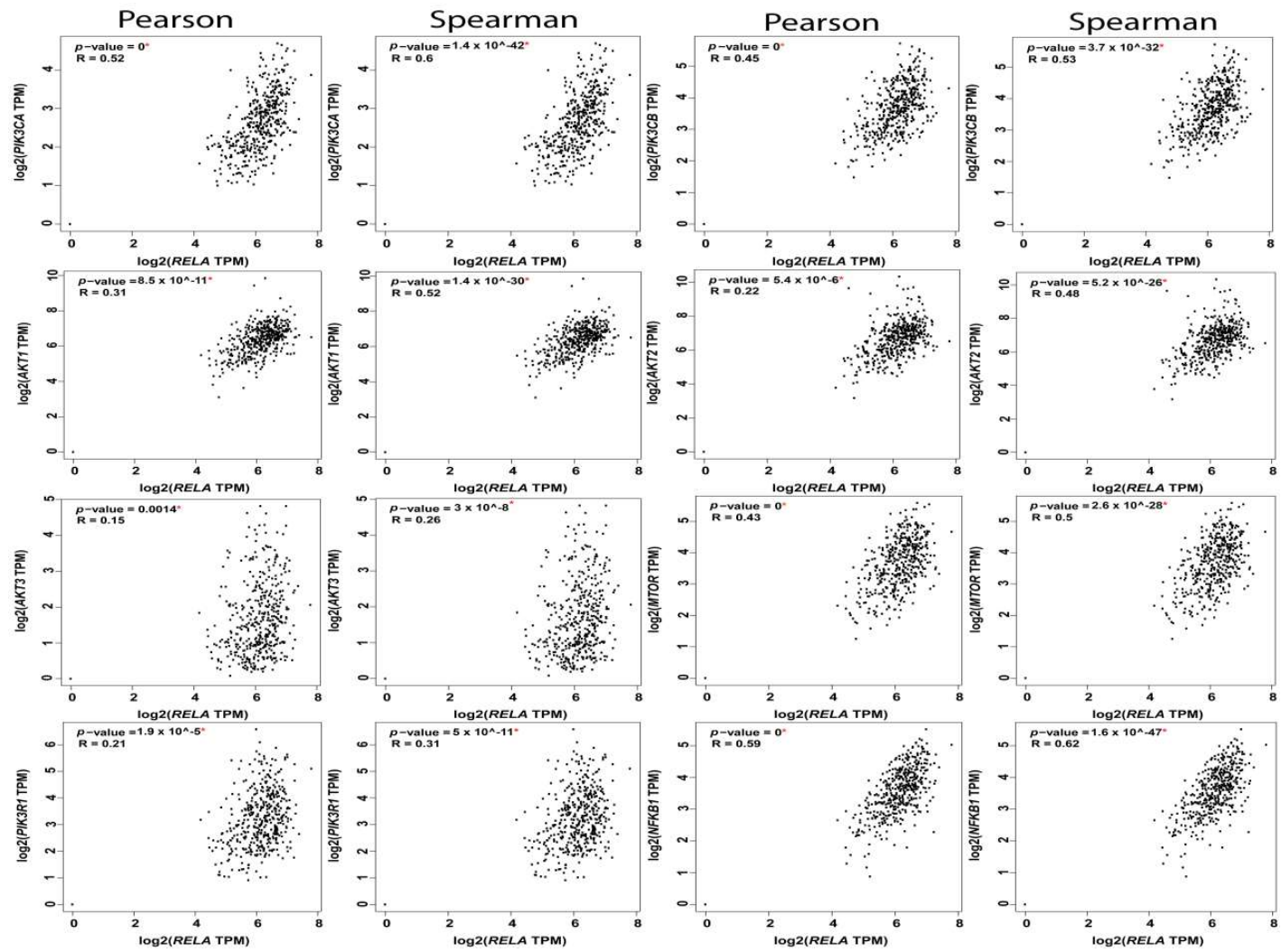

Figure 4. Correlation between RelA and the nodes of PI3K-AKT-mTOR and NFkB pathways.
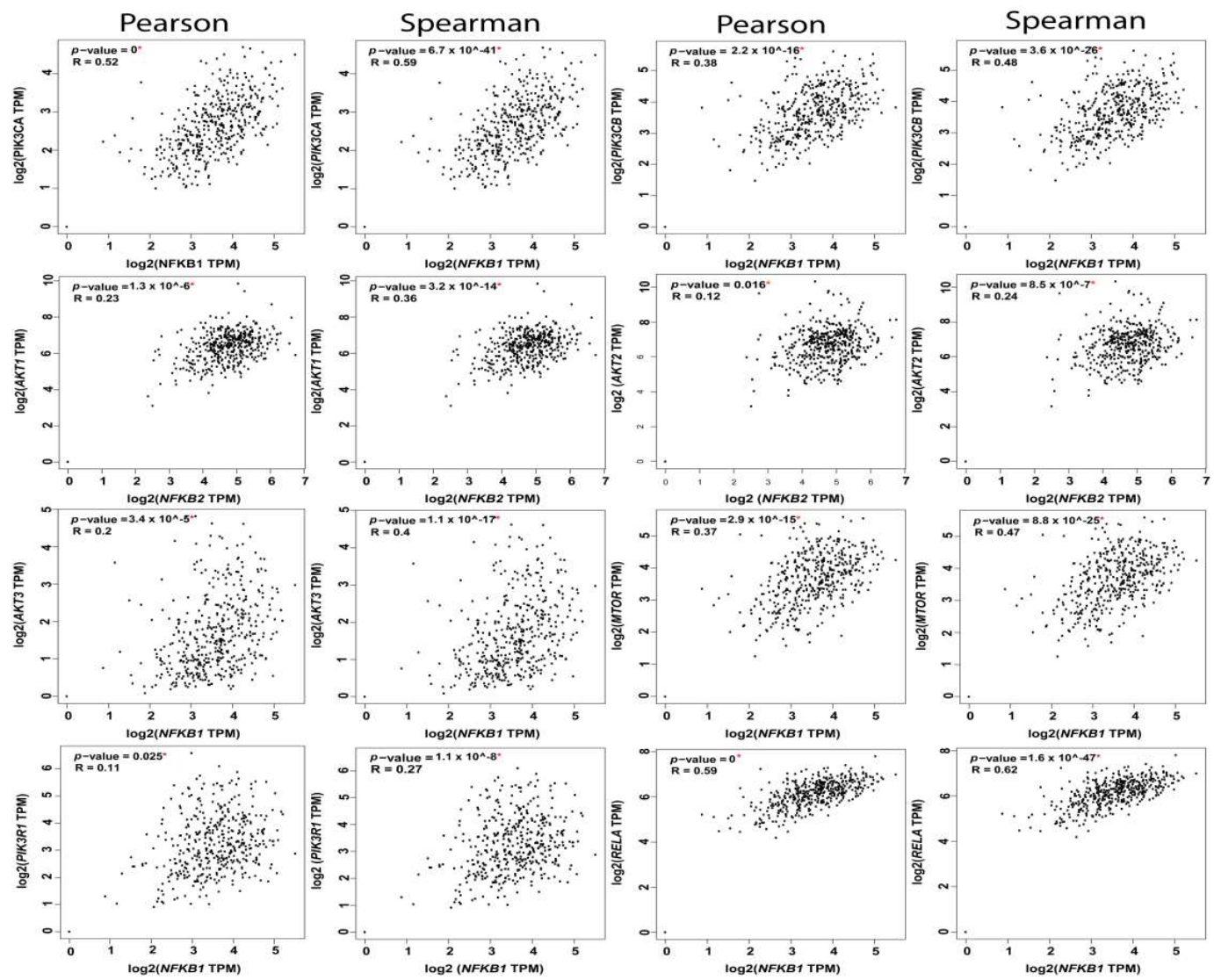

Figure 5. Correlation between NFkB1 subunit and the nodes of PI3K-AKT-mTOR and NFkB pathways. 

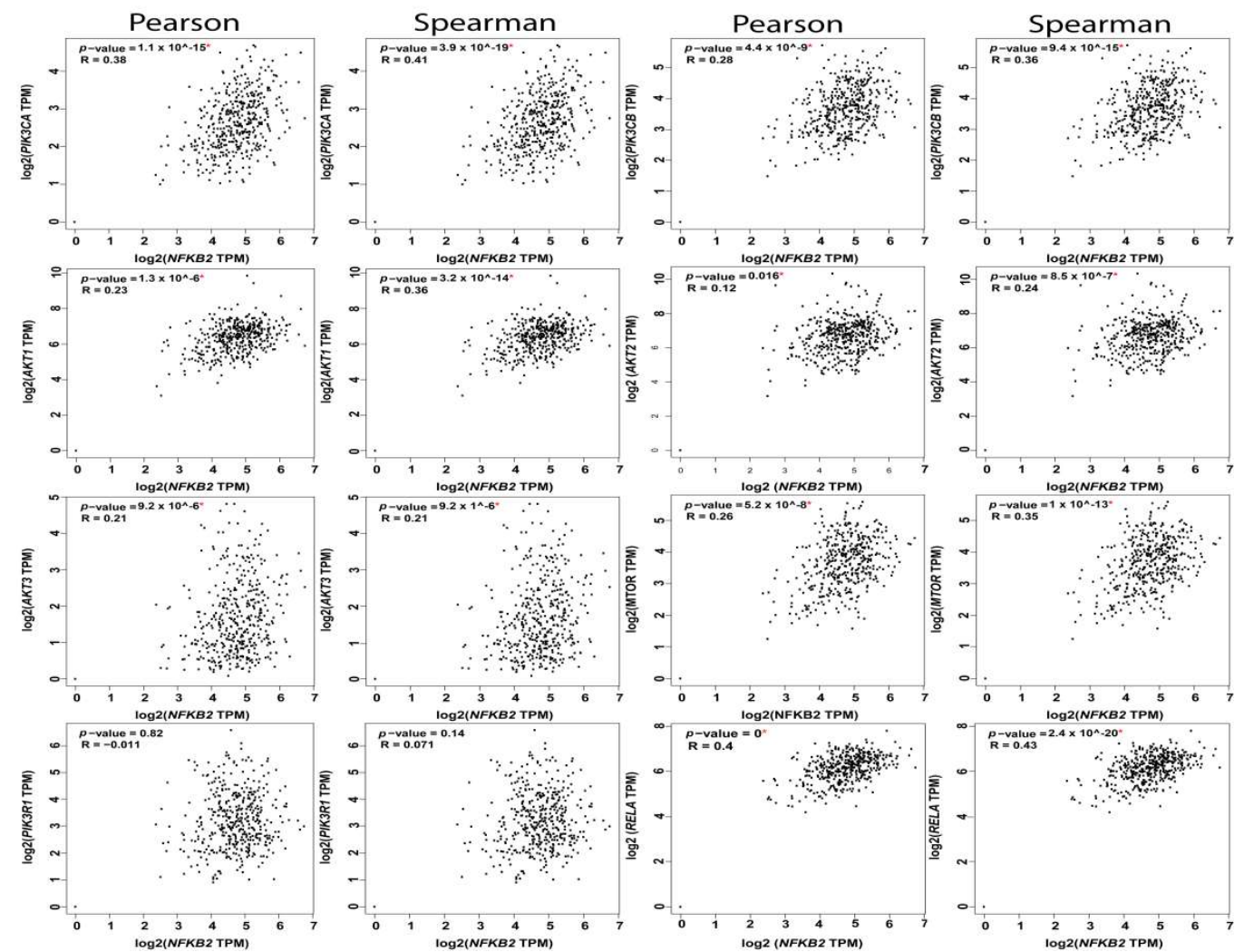

Figure 6. Correlation between NFkB2 subunit and the nodes of PI3K-AKT-mTOR and NFkB pathways.

The PI3K catalytic subunit PI3K-p110 $\alpha$ and its regulatory subunit p 85 have been shown to directly activate NFKB [142-144]. Overexpression of the p110 $\alpha$ subunit induced p65RelA activation and nuclear translocation. Consistently, PI3K inhibitors, LY294002, and wortmannin, as well as the dominant negative regulatory $\mathrm{p} 85$ subunit, inhibited $\mathrm{NF} K \mathrm{~B}$ activation [142]. PI3K/NFKB interaction is induced via a multi-step cascade triggered by the release of pro-inflammatory cytokines [142-144], followed by the interaction between cytokine receptors in the cytoplasm with the regulatory p85 subunit of PI3K, which in turn increases PI3K $110 \alpha$ catalytic activity. Consequently, activated PI3K $110 \alpha$ phosphorylates downstream p65RelA of NFKB followed by its nuclear translocation [142-144]. PI3K activation also phosphorylates AKT with subsequent activation of the p65RelA subunit of NFKB via phosphorylation at S534 through the IKK complex. Phospho-AKT mediates the phosphorylation of IKK $\alpha$ at Thr23, allowing for IKK $\alpha$ to phosphorylate IkB, labelling it for polyubiquitination and proteasomal degradation and phosphorylate p65RelA at S534, and hence allowing NFKB to translocate into the nucleus [145]. Furthermore, the activation of the Ras-PI3K-AKT cascade and the p38 mitogen-activated protein kinase induced NFkB activation through binding of its co-activator cAMP responsive element binding protein (CREB) [146]. Moreover, AKT can activate NFkB independent of IKK by directly phosphorylating the transactivation domain (TAD1) of the p65RelA subunit [146].

The complex crosstalk between the PI3K pathway and NFKB results in decreased survival rates in OvCa patients [147]. High expression levels of the p65 RelA subunit of NFkB, along with cleaved caspase 3, conferred poor outcomes in OvCa patients [148]. NFKB expression levels were strongly associated with chemoresistance. Mabuchi et al. [149] demonstrated that inhibition of NFKB resulted in enhanced efficacy of cisplatin in in vitro and in vivo OvCa models. Upregulation of p65 RelA subunit of NFKB increased the resistance of OvCa to carboplatin [149], and significantly enhanced the aggressiveness of OvCa cells [150]. The ability of $\mathrm{NF} \kappa \mathrm{B}$ to influence OvCa chemoresistance was attributed, in part, to its interactions with Homeobox (HOX) transcript antisense RNA (HOTAIR), a long non-coding RNA (lncRNA) that not only cooperated with NFKB to induce platinum resistance, but also decreased $\operatorname{IkB} \alpha$, allowing for constitutive activation of $N F \kappa B$, suggesting a positive feedback 
loop during the DNA damage response that enhances cellular senescence and chemoresistance in OvCa [151].

\section{6. mTORC1 and NFKB Activation}

mTOR downstream from AKT controls NFKB activity in PTEN-null/inactive cancer cells via interaction with and stimulation of IKK. The mTOR-associated protein Raptor is required for the ability of AKT to induce NFKB activity. This was further supported by inhibiting IKK activity in PTEN-deficient prostate cancer cells by the mTOR inhibitor rapamycin through a mechanism that may involve dissociation of Raptor from mTOR [152]. Paradoxically, IKK $\alpha$ has been shown to regulate mTORC1 activity in PTEN-deficient cancer cells $[153,154]$. In contrast, IKK $\beta$ activates mTORC1 in an AKT-dependent manner [152], and in an AKT-independent manner through the phosphorylation of the mTOR repressor TSC1 at S487 and S511 [155]. The regulation of mTORC1 by IKK $\beta$ suggests a reciprocal activation of IKK $\beta$ by mTORC1, leading to activation of a NFkB canonical pathway $[152,156]$.

\section{Therapeutic Targeting of PI3K-AKT-mTOR-NFKB in Preclinical Models of OvCa}

The PI3K-AKT-mTOR-NFкB pathway is responsible not only for the aggressiveness of OvCa, but also contributes to the increased resistance to the standard chemotherapeutics, cisplatin and paclitaxel [157]. Recent decades have witnessed an unparalleled expansion of therapeutic agents designed to target the PI3K/AKT/mTOR/NFkB pathway.

Several preclinical studies indicate the effectiveness of PI3K inhibitors in OvCa, either alone or in combination with other therapies. For example, isoform-specific $\mathrm{p} 110 \beta$ inhibitors have demonstrated a strong potency, especially against PTEN-deficient cell lines [158]. While some preclinical data suggests that OvCa cells with simultaneous mutations in KRAS and loss of PTEN depend more heavily on p110 $\alpha$ than $\mathrm{p} 110 \beta$ [159], concurrent inhibition of $\mathrm{p} 110 \alpha$ and $\mathrm{p} 110 \beta$ may yield optimal tumoricidal activity in OvCa [160]. Both $\mathrm{p} 110 \alpha$ and $\mathrm{p} 110 \beta$ isoforms exhibit overlapping roles and the success of $\mathrm{p} 110 \beta$ specific inhibitors likely depends on the absence of p110 $\alpha$-activating mutations [161]. A combination of PARP inhibitor, Olaparib, and PI3K inhibitor, BKM120, effectively blocked the proliferation of OvCa cells with an intensified DNA damage response blockade in vitro, and synergistically inhibited the growth of PIK3CA mutant OvCa cells SKOV3, IGROV1, and HEYA8 cells. Additionally, BKM120 synergized with Olaparib to increase apoptosis as well as inhibit migration and invasion of PIK3CA mutant OvCa cells [162]. Interestingly, OvCa cells that responded favorably to the combination treatment demonstrated decreased BRCA1/2 expression and decreased intraperitoneal dissemination [162]. Combining the DNA-damaging drug, doxorubicin, with a class I PI3K inhibitor, GDC-0941, in OvCa preclinical studies showed that PI3K inhibition significantly increased apoptosis, DNA damage, and the overall anti-tumorigenic effects of doxorubicin [163].

AKT protein expression was significantly increased in cisplatin-resistant A2780 OvCa cells (A2780cis) as compared to its cisplatin-sensitive counterpart $[99,100]$. This platinum resistance in the A2780cis cell line was overcome by AKT downregulation by siRNA [99]. The polyadenylation inhibitor cordycepin, also known as $3^{\prime}$-deoxyadenosine [164,165], has been shown to induce apoptosis and inhibit OvCa cell migration through inhibition of CCL5-induced AKT-NFkB signaling pathway [165]. Consistently, Aurora-A inhibitor, MK-5108, induced cell cycle arrest by inhibiting the p65 subunit of NFKB and led to the nuclear accumulation of $\mathrm{I} \kappa \mathrm{B} \alpha$ [166]. With decreased interleukin-6 (IL-6), interleukin-8 (IL-8), macrophage chemoattractant protein-1 (MCP-1), and Growth-Regulated alpha $(G R O-\alpha)$. Therefore, inhibition of the NFKB pathway demonstrated anti-tumorigenic effects on OvCa stem cells.

Inhibition of the PI3K-NFKB axis also inhibited OvCa stem cells (CSCs) triggered by cisplatin. Disruption of the PI3K-NFKB loop by wortamannin reduced the OvCa CSC subpopulation [167]. A study by Gonzalez-Torres et al. [168] reported that in the SKOV3 cell line, CD44+ cells exhibited increased transcripts of stemness genes NANOG, octamer-binding transcription factor 4/3 (OCT4/3), and sex determing region Y HMG-box 2 (SOX2) with high expression levels of RelA, RelB, and 
IKK $\alpha$. Inhibition of the NFkB canonical pathway by dominant negative IkB $\alpha$, as well as inhibition of non-canonical kinase, IKK $\alpha$, by shRNAs, decreased CSC population with downregulation of stemness genes [168]. Additional studies by House et al., [169] showed that NFkB promotes OvCa tumor initiating cells in two arms: first, via the canonical pathway that supports proliferative cancer cells, and second, via the non-canonical pathway that supports ALDH+ OvCa stem cell like cells (CSLCs). Another study demonstrated that CSLCs produce CCL5, which activates downstream NFkB signaling and allows for the differentiation of CSLCs to endothelial cells (ECs) that participate in tumor angiogenesis and further promote invasion and metastasis of OvCa cells [170].

Preclinical studies of an mTOR inhibitor revealed that CC223 disrupted the assembly of mTORC1-Raptor and mTORC2-Rictor complexes in SKOV3 cells [171]. CC223 was earlier found to inhibit the pro-survival and anti-apoptotic effects of sphingosine kinase 1 (SphK1), which is over-expressed in OvCa cells [172,173]. CC223 also blocked phosphorylation of S6K1 and AKT (Ser473), both of which are indicators of mTOR activity. Moreover, mTOR-dependent proteins, cyclin D1 and hypoxia-inducible factor- $1 \alpha(\mathrm{HIF} 1 \alpha)$, were also decreased upon CC223 treatment together with inhibition of cell survival and proliferation and induction of apoptosis. Furthermore, restoration of mTOR activation by overexpression of a constitutively-active AKT1 (ca-AKT1) form in SKOV3 cells partially mitigated, but did not reverse, CC223-induced cytotoxicity in OvCa cells [171]. Finally, CC223-induced reactive oxygen species (ROS) production in SKOV3 cells and inhibited their in vivo growth in nude mice [171]. Another study demonstrated that a novel PI3K/mTOR dual inhibitor, CMG002, has the ability to overcome the chemo-resistance in OvCa cells to paclitaxel or cisplatin by inhibiting cell proliferation and inducing G1 cell cycle arrest and apoptosis in vitro [174]. In vivo, CMG002 suppressed the growth of OvCa in xenograft in nude mice as a monotherapy, and in combination with paclitaxel or cisplatin. CMG002 markedly inhibited the phosphorylation of mTOR (Ser2448), AKT (Ser473 and Thr308), and ribosomal protein S6 (rpS6, Ser235/236) [174].

\section{Therapeutic Targeting of PI3K-AKT-mTOR-NFKB in Clinical Trials: Opportunities and Challenges}

Due to its multiple downstream effectors, PI3K has become an attractive therapeutic target for OvCa. Several clinical trials that are targeting PI3K in combination with targeting its upstream activators or downstream effectors are ongoing in phase 1 and 2 clinical trials (Table 3). Targeting all Class I PI3K forms by BKM120, or Buparlisib, a dimorpholino pyrimidine derivative [175], is paired with BYL719 (alpelisib), which has targeted phosphatidylinositol 3-kinase $\alpha$-selective forms [176] in a phase 1 trial. Another inhibitor of all PI3K isoforms, Copanlisib, with the greatest inhibitory activity against PI3K $\alpha$ and PI3K $\delta[177,178]$, is in a phase 1 trial with MEK162, or binimetinib, that inhibits MEK1/2. Moreover, CUDC-907, an oral small molecule inhibitor that targets both PI3K and HDAC [179] is in a phase 1 trial.

Drugs targeting AKT include AZD5363 and GSK2141795, both of which are potent pan-AKT inhibitors as well as the cell-permeable tricyclic nucleoside, Triciribine (PTX-200) and the allosteric, selective, non-ATP competitive inhibitor, Miransertib (ARQ 092) are all currently in phase 1 clinical trials. MK2206, another allosteric AKT inhibitor, is currently in phase 2.

Small molecule inhibitors that target mTOR are in phase 2 trials, including sapanisertib, as well as derivatives of macrolide compounds from rapamycin, sirolimus, everolimus, and temsirolimus. Nanoparticle albumin-bound rapamycin, along with MLN0128, an ATP-competitive kinase inhibitor, and AZD2014/vistusertib target mTOR and are in phase 1 trials.

Interestingly, several therapies have been discovered which target multiple effectors. For example, TAK228 targets PI3K/AKT/mTOR and downregulates inflammatory cytokines IL-6 [180], and is currently in a phase 2 trial. Perifosine targets PI3K/AKT/MTOR as well as NFKB [181] and is currently in phase 1 of trials (Table 3). Encapsulated formulation of curcumin together with RTKI and doxorubicin (IMX-110) is currently in a phase $1 / 2$ trial as it has an advantage of targeting cancer cells with doxorubicin 
while inhibiting activation of signal transducer and activator of transcription 3 (STAT3) and NF-kB, as well as PI3K/AKT/mTOR [182,183] by curcumin, thus inhibiting the evolution of resistance $[184,185]$.

While there are several drugs targeting the PI3K pathway under investigation in clinical trials, it is important to address the challenges in the clinical development of these therapies in OvCa. The success of PI3K inhibitors is inherently limited by several factors. One challenge is the toxicity of PI3K inhibitors, which is that largely dependent upon isozyme specificity; pan-PI3K inhibitors have serious side effects including myelosuppression and transaminitis, while PI3K $\alpha$ inhibitors result in hyperglycemia and rash [186]. Therefore, one solution to ameliorate drug toxicity would be the development of isozyme specific PI3K inhibitors with lower toxicity profiles. Another challenge includes feedback upregulation of compensatory pathways. Inhibition of PI3K blocks the phosphorylation of FOXO and thus reverses the suppression of RTKs, leading to the depression of ribosomal protein S6 kinase (S6K) and Growth Factor Receptor Bound Protein 10 (GRB10), and hence resulting in the activation of multiple RTKs and PIP3 production [186]. A similar problem is encountered with therapies that aim to induce NFkB inhibition. This inhibition causes an increased activation of the Nucleotide-Binding Oligomerization Domain, Leucine Rich Repeat And Pyrin Domain Containing 3 (NLRP3, NLR family pyrin domain containing 3) inflammasome, which causes a caspase-1 mediated activation of pro-inflammatory cytokines, IL-1 $\beta$ and IL-18 [187]. While this poses a major setback, it can be rectified by using a combination of therapies [186]. A third challenge in using PI3K inhibitors is the enhanced insulin production upon PI3K inhibition; studies have indicated that there is a dose-dependent increase in plasma levels of C-peptide and insulin with PI3K inhibitors and that this insulin secretion may activate insulin receptors and PI3K, thus reducing the overall clinical efficacy of PI3K inhibitors [176]. However, if PI3K inhibitors are used in combination with sodium-glucose costransporter-2 (SGLT2) inhibitors, or if the patient is placed on a ketogenic diet, this effect may be alleviated [186].

\section{Conclusions}

Among all gynecologic malignancies, HGSC is the most prevalent and lethal subtype. Women are diagnosed at advanced stages and with limited treatment options. The five-year survival for stage III/IV patients is poor and hovers around $30-40 \%$. Recent studies have indicated that the PI3K/AKT/mTOR, as well as NFKB pathways, are highly mutated and hyper-activated in a majority of OvCa patients, and are associated with aggressive disease, therapeutic resistance, recurrence, and an overall poorer prognosis. A comprehensive investigation of the PI3K/AKT/mTOR and their interconnection with the $\mathrm{NF} \kappa \mathrm{B}$ pathway will not only expand our understanding of this ruthless disease, but also enhance the development of more effective and targeted therapies in OvCa.

Author Contributions: Conceptualization, N.S.; methodology, A.G. and N.S. data curation, A.G. and N.S.; writing_original draft preparation, A.G.; writing—review and editing, A.G. and N.S.; supervision, N.S. funding acquisition, N.S.

Funding: This work is supported by Marsha Rivkin Pilot Award, WFBMC Department of Pathology Research Pilot Funds, and R01 CA193437 (NS).

Conflicts of Interest: The authors declare no conflict of interest.

\section{References}

1. Siegel, R.L.; Miller, K.D.; Jemal, A. Cancer statistics, 2019. Ca Cancer J. Clin. 2019, 69, 7-34. [CrossRef] [PubMed]

2. Tang, Z.; Li, C.; Kang, B.; Gao, G.; Li, C.; Zhang, Z. Gepia: A web server for cancer and normal gene expression profiling and interactive analyses. Nucleic Acids Res. 2017, 45, 98-102. [CrossRef] [PubMed]

3. Borley, J.; Wilhelm-Benartzi, C.; Brown, R.; Ghaem-Maghami, S. Does tumour biology determine surgical success in the treatment of epithelial ovarian cancer? A systematic literature review. Br. J. Cancer 2012, 107, 1069-1074. [CrossRef] [PubMed] 
4. Hoskins, W.J.; McGuire, W.P.; Brady, M.F.; Homesley, H.D.; Creasman, W.T.; Berman, M.; Ball, H.; Berek, J.S. The effect of diameter of largest residual disease on survival after primary cytoreductive surgery in patients with suboptimal residual epithelial ovarian carcinoma. Am. J. Obs. Gynecol. 1994, 170, 974-980. [CrossRef]

5. Gasparri, M.L.; Bardhi, E.; Ruscito, I.; Papadia, A.; Farooqi, A.A.; Marchetti, C.; Bogani, G.; Ceccacci, I.; Mueller, M.D.; Benedetti Panici, P. Pi3k/akt/mtor pathway in ovarian cancer treatment: Are we on the right track? Geburtshilfe Frauenheilkd. 2017, 77, 1095-1103. [CrossRef] [PubMed]

6. Mabuchi, S.; Kuroda, H.; Takahashi, R.; Sasano, T. The pi3k/akt/mtor pathway as a therapeutic target in ovarian cancer. Gynecol. Oncol. 2015, 137, 173-179. [CrossRef] [PubMed]

7. Martini, M.; De Santis, M.C.; Braccini, L.; Gulluni, F.; Hirsch, E. Pi3k/akt signaling pathway and cancer: An updated review. Ann. Med. 2014, 46, 372-383. [CrossRef] [PubMed]

8. Huang, J.; Zhang, L.; Greshock, J.; Colligon, T.A.; Wang, Y.; Ward, R.; Katsaros, D.; Lassus, H.; Butzow, R.; Godwin, A.K.; et al. Frequent genetic abnormalities of the pi3k/akt pathway in primary ovarian cancer predict patient outcome. Genes Chromosomes Cancer 2011, 50, 606-618. [CrossRef] [PubMed]

9. Cheaib, B.; Auguste, A.; Leary, A. The pi3k/akt/mtor pathway in ovarian cancer: Therapeutic opportunities and challenges. Chin. J. Cancer 2015, 34, 4-16. [CrossRef]

10. Philp, A.J.; Campbell, I.G.; Leet, C.; Vincan, E.; Rockman, S.P.; Whitehead, R.H.; Thomas, R.J.; Phillips, W.A. The phosphatidylinositol $3^{\prime}$-kinase p85alpha gene is an oncogene in human ovarian and colon tumors. Cancer Res. 2001, 61, 7426-7429.

11. Luo, J.; Manning, B.D.; Cantley, L.C. Targeting the pi3k-akt pathway in human cancer: Rationale and promise. Cancer Cell 2003, 4, 257-262. [CrossRef]

12. Carpten, J.D.; Faber, A.L.; Horn, C.; Donoho, G.P.; Briggs, S.L.; Robbins, C.M.; Hostetter, G.; Boguslawski, S.; Moses, T.Y.; Savage, S.; et al. A transforming mutation in the pleckstrin homology domain of akt1 in cancer. Nature 2007, 448, 439-444. [CrossRef] [PubMed]

13. Nakayama, K.; Nakayama, N.; Kurman, R.J.; Cope, L.; Pohl, G.; Samuels, Y.; Velculescu, V.E.; Wang, T.L.; Shih Ie, M. Sequence mutations and amplification of pik3ca and akt2 genes in purified ovarian serous neoplasms. Cancer Biol. 2006, 5, 779-785. [CrossRef] [PubMed]

14. Martins, F.C.; Santiago, I.; Trinh, A.; Xian, J.; Guo, A.; Sayal, K.; Jimenez-Linan, M.; Deen, S.; Driver, K.; Mack, M.; et al. Combined image and genomic analysis of high-grade serous ovarian cancer reveals pten loss as a common driver event and prognostic classifier. Genome Biol. 2014, 15, 526. [CrossRef] [PubMed]

15. Salmena, L.; Shaw, P.; Fans, I.; Rosen, B.; Risch, H.; Mitchell, C.; Sun, P.; Narod, S.A.; Kotsopoulos, J. Prognostic value of inpp4b protein immunohistochemistry in ovarian cancer. Eur. J. Gynaecol. Oncol. 2015, 36, $260-267$.

16. De Melo, A.C.; Paulino, E.; Garces, A.H. A review of mtor pathway inhibitors in gynecologic cancer. Oxid. Med. Cell Longev. 2017, 2017, 4809751. [CrossRef]

17. Fresno Vara, J.A.; Casado, E.; de Castro, J.; Cejas, P.; Belda-Iniesta, C.; Gonzalez-Baron, M. Pi3k/akt signalling pathway and cancer. Cancer Treat. Rev. 2004, 30, 193-204. [CrossRef] [PubMed]

18. Fruman, D.A.; Rommel, C. Pi3k and cancer: Lessons, challenges and opportunities. Nat. Rev. Drug Discov. 2014, 13, 140-156. [CrossRef]

19. Marshall, J.D.S.; Whitecross, D.E.; Mellor, P.; Anderson, D.H. Impact of p85alpha alterations in cancer. Biomolecules 2019, 9, 29. [CrossRef]

20. Posor, Y.; Eichhorn-Gruenig, M.; Puchkov, D.; Schoneberg, J.; Ullrich, A.; Lampe, A.; Muller, R.; Zarbakhsh, S.; Gulluni, F.; Hirsch, E.; et al. Spatiotemporal control of endocytosis by phosphatidylinositol-3,4-bisphosphate. Nature 2013, 499, 233-237. [CrossRef]

21. Das, M.; Scappini, E.; Martin, N.P.; Wong, K.A.; Dunn, S.; Chen, Y.J.; Miller, S.L.; Domin, J.; O’Bryan, J.P. Regulation of neuron survival through an intersectin-phosphoinositide 3'-kinase c2beta-akt pathway. Mol. Cell Biol. 2007, 27, 7906-7917. [CrossRef] [PubMed]

22. Jean, S.; Kiger, A.A. Classes of phosphoinositide 3-kinases at a glance. J. Cell Sci. 2014, 127, $923-928$. [CrossRef] [PubMed]

23. Zhao, X.; Guan, J.L. Focal adhesion kinase and its signaling pathways in cell migration and angiogenesis. Adv. Drug Deliv. Rev. 2011, 63, 610-615. [CrossRef] [PubMed]

24. Shishido, S.; Bonig, H.; Kim, Y.M. Role of integrin alpha4 in drug resistance of leukemia. Front. Oncol. 2014, 4, e99. [CrossRef] [PubMed]

25. Chalhoub, N.; Baker, S.J. Pten and the pi3-kinase pathway in cancer. Annu. Rev. Pathol. 2009, 4, 127-150. [CrossRef] [PubMed] 
26. Mohamed, A.J.; Yu, L.; Backesjo, C.M.; Vargas, L.; Faryal, R.; Aints, A.; Christensson, B.; Berglof, A.; Vihinen, M.; Nore, B.F.; et al. Bruton's tyrosine kinase (btk): Function, regulation, and transformation with special emphasis on the ph domain. Immunol. Rev. 2009, 228, 58-73. [CrossRef] [PubMed]

27. Vigil, D.; Cherfils, J.; Rossman, K.L.; Der, C.J. Ras superfamily gefs and gaps: Validated and tractable targets for cancer therapy? Nat. Rev. Cancer 2010, 10, 842-857. [CrossRef]

28. Bos, J.L.; Rehmann, H.; Wittinghofer, A. Gefs and gaps: Critical elements in the control of small g proteins. Cell 2007, 129, 865-877. [CrossRef]

29. Fruman, D.A.; Chiu, H.; Hopkins, B.D.; Bagrodia, S.; Cantley, L.C.; Abraham, R.T. The pi3k pathway in human disease. Cell 2017, 170, 605-635. [CrossRef]

30. Vanhaesebroeck, B.; Stephens, L.; Hawkins, P. Pi3k signalling: The path to discovery and understanding. Nat. Rev. Mol. Cell Biol. 2012, 13, 195-203. [CrossRef]

31. Cancer Genome Atlas Research, N. Integrated genomic analyses of ovarian carcinoma. Nature 2011, 474, 609-615. [CrossRef] [PubMed]

32. Thorpe, L.M.; Yuzugullu, H.; Zhao, J.J. Pi3k in cancer: Divergent roles of isoforms, modes of activation and therapeutic targeting. Nat. Rev. Cancer 2015, 15, 7-24. [CrossRef] [PubMed]

33. Shayesteh, L.; Lu, Y.; Kuo, W.L.; Baldocchi, R.; Godfrey, T.; Collins, C.; Pinkel, D.; Powell, B.; Mills, G.B.; Gray, J.W. Pik3ca is implicated as an oncogene in ovarian cancer. Nat. Genet. 1999, 21, 99-102. [CrossRef] [PubMed]

34. Kurman, R.J.; Shih, I.-M. The dualistic model of ovarian carcinogenesis: Revisited, revised, and expanded. Am. J. Pathol. 2016, 186, 733-747. [CrossRef] [PubMed]

35. Cai, J.; Xu, L.; Tang, H.; Yang, Q.; Yi, X.; Fang, Y.; Zhu, Y.; Wang, Z. The role of the pten/pi3k/akt pathway on prognosis in epithelial ovarian cancer: A meta-analysis. Oncologist 2014, 19, 528-535. [CrossRef] [PubMed]

36. Domcke, S.; Sinha, R.; Levine, D.A.; Sander, C.; Schultz, N. Evaluating cell lines as tumour models by comparison of genomic profiles. Nat. Commun. 2013, 4, 2126. [CrossRef] [PubMed]

37. Musa, F.; Schneider, R. Targeting the pi3k/akt/mtor pathway in ovarian cancer. Transl. Cancer Res. 2015, 4, 97-106.

38. Spangle, J.M.; Roberts, T.M.; Zhao, J.J. The emerging role of pi3k/akt-mediated epigenetic regulation in cancer. Biochim. Biophys. Acta Rev. Cancer 2017, 1868, 123-131. [CrossRef]

39. Li, D.; Pan, Y.; Huang, Y.; Zhang, P.; Fang, X. Pak5 induces emt and promotes cell migration and invasion by activating the pi3k/akt pathway in ovarian cancer. Anal. Cell Pathol. 2018, 2018, e8073124. [CrossRef]

40. Liu, P.; Cheng, H.; Roberts, T.M.; Zhao, J.J. Targeting the phosphoinositide 3-kinase pathway in cancer. Nat. Rev. Drug Discov. 2009, 8, 627-644. [CrossRef]

41. Chou, C.H.; Wei, L.H.; Kuo, M.L.; Huang, Y.J.; Lai, K.P.; Chen, C.A.; Hsieh, C.Y. Up-regulation of interleukin-6 in human ovarian cancer cell via a gi/pi3k-akt/nf-kappab pathway by lysophosphatidic acid, an ovarian cancer-activating factor. Carcinogenesis 2005, 26, 45-52. [CrossRef] [PubMed]

42. Dituri, F.; Mazzocca, A.; Giannelli, G.; Antonaci, S. Pi3k functions in cancer progression, anticancer immunity and immune evasion by tumors. Clin. Dev. Immunol. 2011, 2011, 947858. [CrossRef] [PubMed]

43. George, R.J.; Sturmoski, M.A.; Anant, S.; Houchen, C.W. Ep4 mediates pge2 dependent cell survival through the pi3 kinase/akt pathway. Prostaglandins Other Lipid Mediat. 2007, 83, 112-120. [CrossRef] [PubMed]

44. Wu, M.H.; Lo, J.F.; Kuo, C.H.; Lin, J.A.; Lin, Y.M.; Chen, L.M.; Tsai, F.J.; Tsai, C.H.; Huang, C.Y.; Tang, C.H. Endothelin-1 promotes mmp-13 production and migration in human chondrosarcoma cells through fak/pi3k/akt/mtor pathways. J. Cell Physiol. 2012, 227, 3016-3026. [CrossRef] [PubMed]

45. Cheng, W.H.; Lu, P.J.; Hsiao, M.; Hsiao, C.H.; Ho, W.Y.; Cheng, P.W.; Lin, C.T.; Hong, L.Z.; Tseng, C.J. Renin activates pi3k-akt-enos signalling through the angiotensin at(1) and mas receptors to modulate central blood pressure control in the nucleus tractus solitarii. Br. J. Pharm. 2012, 166, 2024-2035. [CrossRef] [PubMed]

46. Cai, H.; Xu, Y. The role of lpa and yap signaling in long-term migration of human ovarian cancer cells. Cell Commun. Signal. 2013, 11, e31. [CrossRef] [PubMed]

47. Mills, G.B.; Moolenaar, W.H. The emerging role of lysophosphatidic acid in cancer. Nat. Rev. Cancer 2003, 3, 582-591. [CrossRef] [PubMed]

48. Cocco, L.; Follo, M.Y.; Manzoli, L.; Suh, P.G. Phosphoinositide-specific phospholipase c in health and disease. J. Lipid Res. 2015, 56, 1853-1860. [CrossRef]

49. Yousif, N.G. Fibronectin promotes migration and invasion of ovarian cancer cells through up-regulation of fak-pi3k/akt pathway. Cell Biol. Int. 2014, 38, 85-91. [CrossRef] 
50. Le Naour, A.; Mevel, R.; Thibault, B.; Courtais, E.; Chantalat, E.; Delord, J.P.; Couderc, B.; Guillermet-Guibert, J.; Martinez, A. Effect of combined inhibition of p110 alpha pi3k isoform and stat 3 pathway in ovarian cancer platinum-based resistance. Oncotarget 2018, 9, 27220-27232. [CrossRef]

51. Kim, S.; Han, Y.; Kim, S.I.; Kim, H.S.; Kim, S.J.; Song, Y.S. Tumor evolution and chemoresistance in ovarian cancer. NPJ Precis. Oncol. 2018, 2, e20. [CrossRef] [PubMed]

52. Carden, C.P.; Stewart, A.; Thavasu, P.; Kipps, E.; Pope, L.; Crespo, M.; Miranda, S.; Attard, G.; Garrett, M.D.; Clarke, P.A.; et al. The association of pi3 kinase signaling and chemoresistance in advanced ovarian cancer. Mol. Cancer 2012, 11, 1609-1617. [CrossRef] [PubMed]

53. Kinross, K.M.; Montgomery, K.G.; Kleinschmidt, M.; Waring, P.; Ivetac, I.; Tikoo, A.; Saad, M.; Hare, L.; Roh, V.; Mantamadiotis, T.; et al. An activating pik3ca mutation coupled with pten loss is sufficient to initiate ovarian tumorigenesis in mice. J. Clin. Investig. 2012, 122, 553-557. [CrossRef] [PubMed]

54. Brasseur, K.; Gevry, N.; Asselin, E. Chemoresistance and targeted therapies in ovarian and endometrial cancers. Oncotarget 2017, 8, 4008-4042. [CrossRef] [PubMed]

55. Liu, Z.; Zhu, G.; Getzenberg, R.H.; Veltri, R.W. The upregulation of pi3k/akt and map kinase pathways is associated with resistance of microtubule-targeting drugs in prostate cancer. J. Cell Biochem. 2015, 116, 1341-1349. [CrossRef] [PubMed]

56. Huang, C.Z.; Wang, Y.F.; Zhang, Y.; Peng, Y.M.; Liu, Y.X.; Ma, F.; Jiang, J.H.; Wang, Q.D. Cepharanthine hydrochloride reverses pglycoprotein-mediated multidrug resistance in human ovarian carcinoma a2780/taxol cells by inhibiting the pi3k/akt signaling pathway. Oncol. Rep. 2017, 38, 2558-2564. [CrossRef] [PubMed]

57. Bumbaca, B.; Li, W. Taxane resistance in castration-resistant prostate cancer: Mechanisms and therapeutic strategies. Acta Pharm. Sin. B 2018, 8, 518-529. [CrossRef] [PubMed]

58. Amini-Farsani, Z.; Sangtarash, M.H.; Shamsara, M.; Teimori, H. Mir-221/222 promote chemoresistance to cisplatin in ovarian cancer cells by targeting pten/pi3k/akt signaling pathway. Cytotechnology 2018, 70, 203-213. [CrossRef]

59. Wu, H.; Cao, Y.; Weng, D.; Xing, H.; Song, X.; Zhou, J.; Xu, G.; Lu, Y.; Wang, S.; Ma, D. Effect of tumor suppressor gene pten on the resistance to cisplatin in human ovarian cancer cell lines and related mechanisms. Cancer Lett. 2008, 271, 260-271. [CrossRef]

60. Wu, H.; Wang, K.; Liu, W.; Hao, Q. Pten overexpression improves cisplatin-resistance of human ovarian cancer cells through upregulating krt10 expression. Biochem. Biophys. Res. Commun. 2014, 444, 141-146. [CrossRef]

61. Peng, D.J.; Wang, J.; Zhou, J.Y.; Wu, G.S. Role of the akt/mtor survival pathway in cisplatin resistance in ovarian cancer cells. Biochem. Biophys. Res. Commun. 2010, 394, 600-605. [CrossRef] [PubMed]

62. Gyorffy, B.; Lanczky, A.; Szallasi, Z. Implementing an online tool for genome-wide validation of survival-associated biomarkers in ovarian-cancer using microarray data from 1287 patients. Endocr. Relat. Cancer 2012, 19, 197-208. [CrossRef] [PubMed]

63. Stratton, M.R.; Campbell, P.J.; Futreal, P.A. The cancer genome. Nature 2009, 458, 719-724. [CrossRef] [PubMed]

64. Previs, R.A.; Sood, A.K.; Mills, G.B.; Westin, S.N. The rise of genomic profiling in ovarian cancer. Expert Rev. Mol. Diagn. 2016, 16, 1337-1351. [CrossRef] [PubMed]

65. Gevaert, O.; Villalobos, V.; Sikic, B.I.; Plevritis, S.K. Identification of ovarian cancer driver genes by using module network integration of multi-omics data. Interface Focus 2013, 3, e20130013. [CrossRef] [PubMed]

66. Manning, B.D.; Cantley, L.C. Akt/pkb signaling: Navigating downstream. Cell 2007, 129, 1261-1274. [CrossRef] [PubMed]

67. Mundi, P.S.; Sachdev, J.; McCourt, C.; Kalinsky, K. Akt in cancer: New molecular insights and advances in drug development. Br. J. Clin. Pharm. 2016, 82, 943-956. [CrossRef] [PubMed]

68. Hutchinson, J.N.; Jin, J.; Cardiff, R.D.; Woodgett, J.R.; Muller, W.J. Activation of akt-1 (pkb-alpha) can accelerate erbb-2-mediated mammary tumorigenesis but suppresses tumor invasion. Cancer Res. 2004, 64, 3171-3178. [CrossRef] [PubMed]

69. Gonzalez, E.; McGraw, T.E. The akt kinases: Isoform specificity in metabolism and cancer. Cell Cycle 2009, 8, 2502-2508. [CrossRef]

70. Linnerth-Petrik, N.M.; Santry, L.A.; Moorehead, R.; Jucker, M.; Wootton, S.K.; Petrik, J. Akt isoform specific effects in ovarian cancer progression. Oncotarget 2016, 7, 74820-74833. [CrossRef] 
71. Fortier, A.M.; Asselin, E.; Cadrin, M. Functional specificity of akt isoforms in cancer progression. Biomol. Concepts 2011, 2, 1-11. [CrossRef] [PubMed]

72. Cho, H.; Thorvaldsen, J.L.; Chu, Q.; Feng, F.; Birnbaum, M.J. Akt1/pkbalpha is required for normal growth but dispensable for maintenance of glucose homeostasis in mice. J. Biol. Chem. 2001, 276, 38349-38352. [CrossRef] [PubMed]

73. Cho, H.; Mu, J.; Kim, J.K.; Thorvaldsen, J.L.; Chu, Q.; Crenshaw, E.B., 3rd; Kaestner, K.H.; Bartolomei, M.S.; Shulman, G.I.; Birnbaum, M.J. Insulin resistance and a diabetes mellitus-like syndrome in mice lacking the protein kinase akt2 (pkb beta). Science 2001, 292, 1728-1731. [CrossRef] [PubMed]

74. Easton, R.M.; Cho, H.; Roovers, K.; Shineman, D.W.; Mizrahi, M.; Forman, M.S.; Lee, V.M.; Szabolcs, M.; de Jong, R.; Oltersdorf, T.; et al. Role for akt3/protein kinase bgamma in attainment of normal brain size. Mol. Cell Biol. 2005, 25, 1869-1878. [CrossRef] [PubMed]

75. Showkat, M.; Beigh, M.A.; Andrabi, K.I. Mtor signaling in protein translation regulation: Implications in cancer genesis and therapeutic interventions. Mol. Biol. Int. 2014, 2014, e686984. [CrossRef] [PubMed]

76. Altomare, D.A.; Wang, H.Q.; Skele, K.L.; De Rienzo, A.; Klein-Szanto, A.J.; Godwin, A.K.; Testa, J.R. Akt and mtor phosphorylation is frequently detected in ovarian cancer and can be targeted to disrupt ovarian tumor cell growth. Oncogene 2004, 23, 5853-5857. [CrossRef] [PubMed]

77. Conciatori, F.; Ciuffreda, L.; Bazzichetto, C.; Falcone, I.; Pilotto, S.; Bria, E.; Cognetti, F.; Milella, M. Mtor cross-talk in cancer and potential for combination therapy. Cancers 2018, 10, 23. [CrossRef] [PubMed]

78. Zois, C.E.; Harris, A.L. Glycogen metabolism has a key role in the cancer microenvironment and provides new targets for cancer therapy. J. Mol. Med. 2016, 94, 137-154. [CrossRef] [PubMed]

79. Roberts, M.S.; Woods, A.J.; Dale, T.C.; Van Der Sluijs, P.; Norman, J.C. Protein kinase b/akt acts via glycogen synthase kinase 3 to regulate recycling of alpha v beta 3 and alpha 5 beta 1 integrins. Mol. Cell Biol. 2004, 24, 1505-1515. [CrossRef] [PubMed]

80. Datta, S.R.; Dudek, H.; Tao, X.; Masters, S.; Fu, H.; Gotoh, Y.; Greenberg, M.E. Akt phosphorylation of bad couples survival signals to the cell-intrinsic death machinery. Cell 1997, 91, 231-241. [CrossRef]

81. Tzivion, G.; Dobson, M.; Ramakrishnan, G. Foxo transcription factors; regulation by akt and 14-3-3 proteins. Biochim. Biophys. Acta 2011, 1813, 1938-1945. [CrossRef] [PubMed]

82. Mayo, L.D.; Donner, D.B. A phosphatidylinositol 3-kinase/akt pathway promotes translocation of mdm2 from the cytoplasm to the nucleus. Proc. Natl. Acad. Sci. USA 2001, 98, 11598-11603. [CrossRef] [PubMed]

83. Gottlieb, T.M.; Leal, J.F.; Seger, R.; Taya, Y.; Oren, M. Cross-talk between akt, p53 and mdm2: Possible implications for the regulation of apoptosis. Oncogene 2002, 21, 1299-1303. [CrossRef] [PubMed]

84. Huang, J.; Manning, B.D. The tsc1-tsc2 complex: A molecular switchboard controlling cell growth. Biochem. J. 2008, 412, 179-190. [CrossRef] [PubMed]

85. Qin, X.; Jiang, B.; Zhang, Y. 4e-bp1, a multifactor regulated multifunctional protein. Cell Cycle 2016, 15, 781-786. [CrossRef] [PubMed]

86. Georgescu, M.M. Pten tumor suppressor network in pi3k-akt pathway control. Genes Cancer 2010, 1, 1170-1177. [CrossRef] [PubMed]

87. Blanco-Aparicio, C.; Renner, O.; Leal, J.F.; Carnero, A. Pten, more than the akt pathway. Carcinogenesis 2007, 28, 1379-1386. [CrossRef] [PubMed]

88. Alimonti, A.; Carracedo, A.; Clohessy, J.G.; Trotman, L.C.; Nardella, C.; Egia, A.; Salmena, L.; Sampieri, K.; Haveman, W.J.; Brogi, E.; et al. Subtle variations in pten dose determine cancer susceptibility. Nat. Genet. 2010, 42, 454-458. [CrossRef] [PubMed]

89. Jia, S.; Liu, Z.; Zhang, S.; Liu, P.; Zhang, L.; Lee, S.H.; Zhang, J.; Signoretti, S.; Loda, M.; Roberts, T.M.; et al. Essential roles of pi(3)k-p110beta in cell growth, metabolism and tumorigenesis. Nature 2008, 454, 776-779. [CrossRef]

90. Terakawa, N.; Kanamori, Y.; Yoshida, S. Loss of pten expression followed by akt phosphorylation is a poor prognostic factor for patients with endometrial cancer. Endocr. Relat. Cancer 2003, 10, 203-208. [CrossRef]

91. Tachibana, M.; Shibakita, M.; Ohno, S.; Kinugasa, S.; Yoshimura, H.; Ueda, S.; Fujii, T.; Rahman, M.A.; Dhar, D.K.; Nagasue, N. Expression and prognostic significance of pten product protein in patients with esophageal squamous cell carcinoma. Cancer 2002, 94, 1955-1960. [CrossRef] [PubMed]

92. Leupin, N.; Cenni, B.; Novak, U.; Hugli, B.; Graber, H.U.; Tobler, A.; Fey, M.F. Disparate expression of the pten gene: A novel finding in b-cell chronic lymphocytic leukaemia (b-cll). Br. J. Haematol. 2003, 121, 97-100. [CrossRef] [PubMed] 
93. Cheong, J.W.; Eom, J.I.; Maeng, H.Y.; Lee, S.T.; Hahn, J.S.; Ko, Y.W.; Min, Y.H. Phosphatase and tensin homologue phosphorylation in the c-terminal regulatory domain is frequently observed in acute myeloid leukaemia and associated with poor clinical outcome. Br. J. Haematol. 2003, 122, 454-456. [CrossRef] [PubMed]

94. Ip, L.R.; Poulogiannis, G.; Viciano, F.C.; Sasaki, J.; Kofuji, S.; Spanswick, V.J.; Hochhauser, D.; Hartley, J.A.; Sasaki, T.; Gewinner, C.A. Loss of inpp4b causes a DNA repair defect through loss of brca1, atm and atr and can be targeted with parp inhibitor treatment. Oncotarget 2015, 6, 10548-10562. [CrossRef] [PubMed]

95. Fedele, C.G.; Ooms, L.M.; Ho, M.; Vieusseux, J.; O’Toole, S.A.; Millar, E.K.; Lopez-Knowles, E.; Sriratana, A.; Gurung, R.; Baglietto, L.; et al. Inositol polyphosphate 4-phosphatase ii regulates pi3k/akt signaling and is lost in human basal-like breast cancers. Proc. Natl. Acad. Sci. USA 2010, 107, 22231-22236. [CrossRef] [PubMed]

96. Chen, Y.; Sun, Z.; Qi, M.; Wang, X.; Zhang, W.; Chen, C.; Liu, J.; Zhao, W. Inpp4b restrains cell proliferation and metastasis via regulation of the pi3k/akt/sgk pathway. J. Cell Mol. Med. 2018, 22, 2935-2943. [CrossRef]

97. Gewinner, C.; Wang, Z.C.; Richardson, A.; Teruya-Feldstein, J.; Etemadmoghadam, D.; Bowtell, D.; Barretina, J.; Lin, W.M.; Rameh, L.; Salmena, L.; et al. Evidence that inositol polyphosphate 4-phosphatase type ii is a tumor suppressor that inhibits pi3k signaling. Cancer Cell 2009, 16, 115-125. [CrossRef]

98. Hanrahan, A.J.; Schultz, N.; Westfal, M.L.; Sakr, R.A.; Giri, D.D.; Scarperi, S.; Janakiraman, M.; Olvera, N.; Stevens, E.V.; She, Q.B.; et al. Genomic complexity and akt dependence in serous ovarian cancer. Cancer Discov. 2012, 2, 56-67. [CrossRef]

99. Hahne, J.C.; Honig, A.; Meyer, S.R.; Gambaryan, S.; Walter, U.; Wischhusen, J.; Haussler, S.F.; Segerer, S.E.; Fujita, N.; Dietl, J.; et al. Downregulation of akt reverses platinum resistance of human ovarian cancers in vitro. Oncol. Rep. 2012, 28, 2023-2028. [CrossRef]

100. Hahne, J.C.; Meyer, S.R.; Gambaryan, S.; Walter, U.; Dietl, J.; Engel, J.B.; Honig, A. Immune escape of akt overexpressing ovarian cancer cells. Int. J. Oncol. 2013, 42, 1630-1635. [CrossRef]

101. Kim, S.H.; Juhnn, Y.S.; Song, Y.S. Akt involvement in paclitaxel chemoresistance of human ovarian cancer cells. Ann. NY Acad. Sci. 2007, 1095, 82-89. [CrossRef] [PubMed]

102. Beauchamp, E.M.; Platanias, L.C. The evolution of the tor pathway and its role in cancer. Oncogene 2013, 32, 3923-3932. [CrossRef] [PubMed]

103. Yang, H.; Rudge, D.G.; Koos, J.D.; Vaidialingam, B.; Yang, H.J.; Pavletich, N.P. Mtor kinase structure, mechanism and regulation. Nature 2013, 497, 217-223. [CrossRef] [PubMed]

104. Baretic, D.; Williams, R.L. The structural basis for mtor function. Semin. Cell Dev. Biol. 2014, 36, 91-101. [CrossRef] [PubMed]

105. Yip, C.K.; Murata, K.; Walz, T.; Sabatini, D.M.; Kang, S.A. Structure of the human mtor complex i and its implications for rapamycin inhibition. Mol. Cell 2010, 38, 768-774. [CrossRef] [PubMed]

106. Bai, H.; Li, H.; Li, W.; Gui, T.; Yang, J.; Cao, D.; Shen, K. The pi3k/akt/mtor pathway is a potential predictor of distinct invasive and migratory capacities in human ovarian cancer cell lines. Oncotarget 2015, 6, 25520-25532. [CrossRef]

107. Yaba, A.; Bianchi, V.; Borini, A.; Johnson, J. A putative mitotic checkpoint dependent on mtor function controls cell proliferation and survival in ovarian granulosa cells. Reprod. Sci. 2008, 15, 128-138. [CrossRef]

108. Guertin, D.A.; Sabatini, D.M. Defining the role of mtor in cancer. Cancer Cell 2007, 12, 9-22. [CrossRef]

109. Wullschleger, S.; Loewith, R.; Hall, M.N. Tor signaling in growth and metabolism. Cell 2006, 124, 471-484. [CrossRef]

110. Hong, Z.; Pedersen, N.M.; Wang, L.; Torgersen, M.L.; Stenmark, H.; Raiborg, C. Ptdins3p controls mtorc1 signaling through lysosomal positioning. J. Cell Biol. 2017, 216, 4217-4233. [CrossRef]

111. Yuan, H.X.; Russell, R.C.; Guan, K.L. Regulation of pik3c3/vps34 complexes by mtor in nutrient stress-induced autophagy. Autophagy 2013, 9, 1983-1995. [CrossRef] [PubMed]

112. Kim, Y.C.; Guan, K.L. Mtor: A pharmacologic target for autophagy regulation. J. Clin. Investig. 2015, 125, 25-32. [CrossRef] [PubMed]

113. Musa, J.; Orth, M.F.; Dallmayer, M.; Baldauf, M.; Pardo, C.; Rotblat, B.; Kirchner, T.; Leprivier, G.; Grunewald, T.G. Eukaryotic initiation factor 4e-binding protein 1 (4e-bp1): A master regulator of mrna translation involved in tumorigenesis. Oncogene 2016, 35, 4675-4688. [CrossRef] [PubMed]

114. Wang, R.; Ganesan, S.; Zheng, X.F. Yin and yang of 4e-bp1 in cancer. Cell Cycle 2016, 15, 1401-1402. [CrossRef] [PubMed] 
115. Ding, M.; Van der Kwast, T.H.; Vellanki, R.N.; Foltz, W.D.; McKee, T.D.; Sonenberg, N.; Pandolfi, P.P.; Koritzinsky, M.; Wouters, B.G. The mtor targets 4e-bp1/2 restrain tumor growth and promote hypoxia tolerance in pten-driven prostate cancer. Mol. Cancer Res. 2018, 16, 682-695. [CrossRef] [PubMed]

116. Barnhart, B.C.; Lam, J.C.; Young, R.M.; Houghton, P.J.; Keith, B.; Simon, M.C. Effects of 4e-bp1 expression on hypoxic cell cycle inhibition and tumor cell proliferation and survival. Cancer Biol. 2008, 7, 1441-1449. [CrossRef]

117. Braunstein, S.; Karpisheva, K.; Pola, C.; Goldberg, J.; Hochman, T.; Yee, H.; Cangiarella, J.; Arju, R.; Formenti, S.C.; Schneider, R.J. A hypoxia-controlled cap-dependent to cap-independent translation switch in breast cancer. Mol. Cell 2007, 28, 501-512. [CrossRef]

118. Liu, P.; Gan, W.; Chin, Y.R.; Ogura, K.; Guo, J.; Zhang, J.; Wang, B.; Blenis, J.; Cantley, L.C.; Toker, A.; et al. Ptdins(3,4,5)p3-dependent activation of the mtorc2 kinase complex. Cancer Discov. 2015, 5, 1194-1209. [CrossRef]

119. Yang, G.; Murashige, D.S.; Humphrey, S.J.; James, D.E. A positive feedback loop between akt and mtorc2 via sin1 phosphorylation. Cell Rep. 2015, 12, 937-943. [CrossRef]

120. Huang, J.; Dibble, C.C.; Matsuzaki, M.; Manning, B.D. The tsc1-tsc2 complex is required for proper activation of mtor complex 2. Mol. Cell Biol. 2008, 28, 4104-4115. [CrossRef]

121. Thobe, K.; Sers, C.; Siebert, H. Unraveling the regulation of mtorc2 using logical modeling. Cell Commun. Signal. 2017, 15, 6. [CrossRef] [PubMed]

122. Sarbassov, D.D.; Guertin, D.A.; Ali, S.M.; Sabatini, D.M. Phosphorylation and regulation of akt/pkb by the rictor-mtor complex. Science 2005, 307, 1098-1101. [CrossRef]

123. Oh, W.J.; Jacinto, E. Mtor complex 2 signaling and functions. Cell Cycle 2011, 10, 2305-2316. [CrossRef]

124. Cheng, J.; Zhang, D.; Kim, K.; Zhao, Y.; Zhao, Y.; Su, B. Mip1, an mekk2-interacting protein, controls mekk2 dimerization and activation. Mol. Cell Biol. 2005, 25, 5955-5964. [CrossRef] [PubMed]

125. Liu, J.; Wu, D.C.; Qu, L.H.; Liao, H.Q.; Li, M.X. The role of mtor in ovarian cancer, polycystic ovary syndrome and ovarian aging. Clin. Anat. 2018, 31, 891-898. [CrossRef]

126. Castellvi, J.; Garcia, A.; Rojo, F.; Ruiz-Marcellan, C.; Gil, A.; Baselga, J.; Ramon y Cajal, S. Phosphorylated 4e binding protein 1: A hallmark of cell signaling that correlates with survival in ovarian cancer. Cancer 2006, 107, 1801-1811. [CrossRef] [PubMed]

127. Gilmore, T.D. Introduction to nf-kappab: Players, pathways, perspectives. Oncogene 2006, 25, 6680-6684. [CrossRef]

128. Zheng, C.; Yin, Q.A.; Wu, H. Structural studies of nf-kappa b signaling. Cell Res. 2011, 21, 183-195. [CrossRef]

129. Hayden, M.S.; Ghosh, S. Shared principles in nf-kappab signaling. Cell 2008, 132, 344-362. [CrossRef]

130. Karin, M.; Delhase, M. The i kappa b kinase (ikk) and nf-kappa b: Key elements of proinflammatory signalling. Semin. Immunol. 2000, 12, 85-98. [CrossRef]

131. Hunter, J.E.; Leslie, J.; Perkins, N.D. C-rel and its many roles in cancer: An old story with new twists. Br. J. Cancer 2016, 114, 1-6. [CrossRef] [PubMed]

132. Sun, S.C. The noncanonical nf-kappab pathway. Immunol. Rev. 2012, 246, 125-140. [CrossRef] [PubMed]

133. Ling, L.; Cao, Z.; Goeddel, D.V. Nf-kappab-inducing kinase activates ikk-alpha by phosphorylation of ser-176. Proc. Natl. Acad. Sci. USA 1998, 95, 3792-3797. [CrossRef] [PubMed]

134. Uno, M.; Saitoh, Y.; Mochida, K.; Tsuruyama, E.; Kiyono, T.; Imoto, I.; Inazawa, J.; Yuasa, Y.; Kubota, T.; Yamaoka, S. Nf-kappab inducing kinase, a central signaling component of the non-canonical pathway of nf-kappab, contributes to ovarian cancer progression. PLoS ONE 2014, 9, e88347. [CrossRef] [PubMed]

135. Rothgiesser, K.M.; Fey, M.; Hottiger, M.O. Acetylation of p65 at lysine 314 is important for late nf-kappab-dependent gene expression. Bmc. Genom. 2010, 11, 22. [CrossRef] [PubMed]

136. Greene, W.C.; Chen, L.F. Regulation of nf-kappab action by reversible acetylation. Novartis. Found. Symp. 2004, 259, 208-222.

137. Sachdev, S.; Hoffmann, A.; Hannink, M. Nuclear localization of ikappab alpha is mediated by the second ankyrin repeat: The ikappab alpha ankyrin repeats define a novel class of cis-acting nuclear import sequences. Mol. Cell Biol. 1998, 18, 2524-2534. [CrossRef]

138. Baltimore, D. Nf-kappab is 25. Nat. Immunol. 2011, 12, 683-685. [CrossRef]

139. Chen, L.F.; Greene, W.C. Regulation of distinct biological activities of the nf-kappab transcription factor complex by acetylation. J. Mol. Med. 2003, 81, 549-557. [CrossRef] 
140. Benezra, M.; Chevallier, N.; Morrison, D.J.; MacLachlan, T.K.; El-Deiry, W.S.; Licht, J.D. Brca1 augments transcription by the nf-kappab transcription factor by binding to the rel domain of the p65/rela subunit. J. Biol. Chem. 2003, 278, 26333-26341. [CrossRef]

141. Harte, M.T.; Gorski, J.J.; Savage, K.I.; Purcell, J.W.; Barros, E.M.; Burn, P.M.; McFarlane, C.; Mullan, P.B.; Kennedy, R.D.; Perkins, N.D.; et al. Nf-kappab is a critical mediator of brca1-induced chemoresistance. Oncogene 2014, 33, 713-723. [CrossRef] [PubMed]

142. Sizemore, N.; Leung, S.; Stark, G.R. Activation of phosphatidylinositol 3-kinase in response to interleukin-1 leads to phosphorylation and activation of the nf-kappab p65/rela subunit. Mol. Cell Biol. 1999, 19, 4798-4805. [CrossRef] [PubMed]

143. Reddy, S.A.; Huang, J.H.; Liao, W.S. Phosphatidylinositol 3-kinase in interleukin 1 signaling. Physical interaction with the interleukin 1 receptor and requirement in nfkappab and ap-1 activation. J. Biol. Chem. 1997, 272, 29167-29173. [CrossRef] [PubMed]

144. Koul, D.; Yao, Y.; Abbruzzese, J.L.; Yung, W.K.; Reddy, S.A. Tumor suppressor mmac/pten inhibits cytokine-induced nfkappab activation without interfering with the ikappab degradation pathway. J. Biol. Chem. 2001, 276, 11402-11408. [CrossRef] [PubMed]

145. Ozes, O.N.; Mayo, L.D.; Gustin, J.A.; Pfeffer, S.R.; Pfeffer, L.M.; Donner, D.B. Nf-kappab activation by tumour necrosis factor requires the akt serine-threonine kinase. Nature 1999, 401, 82-85. [CrossRef] [PubMed]

146. Madrid, L.V.; Mayo, M.W.; Reuther, J.Y.; Baldwin, A.S., Jr. Akt stimulates the transactivation potential of the rela/p65 subunit of nf-kappa b through utilization of the ikappa b kinase and activation of the mitogen-activated protein kinase p38. J. Biol. Chem. 2001, 276, 18934-18940. [CrossRef] [PubMed]

147. Annunziata, C.M.; Stavnes, H.T.; Kleinberg, L.; Berner, A.; Hernandez, L.F.; Birrer, M.J.; Steinberg, S.M.; Davidson, B.; Kohn, E.C. Nuclear factor kappab transcription factors are coexpressed and convey a poor outcome in ovarian cancer. Cancer 2010, 116, 3276-3284. [CrossRef] [PubMed]

148. Kleinberg, L.; Dong, H.P.; Holth, A.; Risberg, B.; Trope, C.G.; Nesland, J.M.; Florenes, V.A.; Davidson, B. Cleaved caspase-3 and nuclear factor-kappab p65 are prognostic factors in metastatic serous ovarian carcinoma. Hum. Pathol. 2009, 40, 795-806. [CrossRef]

149. Jinawath, N.; Vasoontara, C.; Jinawath, A.; Fang, X.; Zhao, K.; Yap, K.L.; Guo, T.; Lee, C.S.; Wang, W.; Balgley, B.M.; et al. Oncoproteomic analysis reveals co-upregulation of rela and stat5 in carboplatin resistant ovarian carcinoma. PLoS ONE 2010, 5, e11198. [CrossRef]

150. Hernandez, L.; Hsu, S.C.; Davidson, B.; Birrer, M.J.; Kohn, E.C.; Annunziata, C.M. Activation of nf-kappab signaling by inhibitor of nf-kappab kinase beta increases aggressiveness of ovarian cancer. Cancer Res. 2010, 70, 4005-4014. [CrossRef]

151. Ozes, A.R.; Miller, D.F.; Ozes, O.N.; Fang, F.; Liu, Y.; Matei, D.; Huang, T.; Nephew, K.P. Nf-kappab-hotair axis links DNA damage response, chemoresistance and cellular senescence in ovarian cancer. Oncogene 2016, 35, 5350-5361. [CrossRef] [PubMed]

152. Dan, H.C.; Cooper, M.J.; Cogswell, P.C.; Duncan, J.A.; Ting, J.P.; Baldwin, A.S. Akt-dependent regulation of nf-\{kappa\}b is controlled by mtor and raptor in association with ikk. Genes Dev. 2008, 22, 1490-1500. [CrossRef] [PubMed]

153. Dan, H.C.; Adli, M.; Baldwin, A.S. Regulation of mammalian target of rapamycin activity in pten-inactive prostate cancer cells by i kappa b kinase alpha. Cancer Res. 2007, 67, 6263-6269. [CrossRef] [PubMed]

154. Dan, H.C.; Ebbs, A.; Pasparakis, M.; Van Dyke, T.; Basseres, D.S.; Baldwin, A.S. Akt-dependent activation of mtorc1 complex involves phosphorylation of mtor (mammalian target of rapamycin) by ikappab kinase alpha (ikkalpha). J. Biol. Chem. 2014, 289, 25227-25240. [CrossRef] [PubMed]

155. Lee, D.F.; Kuo, H.P.; Chen, C.T.; Hsu, J.M.; Chou, C.K.; Wei, Y.; Sun, H.L.; Li, L.Y.; Ping, B.; Huang, W.C.; et al. Ikk beta suppression of tsc1 links inflammation and tumor angiogenesis via the mtor pathway. Cell 2007, 130, 440-455. [CrossRef] [PubMed]

156. Li, Z.; Yang, Z.; Passaniti, A.; Lapidus, R.G.; Liu, X.; Cullen, K.J.; Dan, H.C. A positive feedback loop involving egfr/akt/mtorc1 and ikk/nf-kb regulates head and neck squamous cell carcinoma proliferation. Oncotarget 2016, 7, 31892-31906.

157. Godwin, P.; Baird, A.M.; Heavey, S.; Barr, M.P.; O’Byrne, K.J.; Gately, K. Targeting nuclear factor-kappa $b$ to overcome resistance to chemotherapy. Front. Oncol. 2013, 3, e120. [CrossRef] 
158. Ni, J.; Liu, Q.; Xie, S.; Carlson, C.; Von, T.; Vogel, K.; Riddle, S.; Benes, C.; Eck, M.; Roberts, T.; et al. Functional characterization of an isoform-selective inhibitor of pi3k-p110beta as a potential anticancer agent. Cancer Discov. 2012, 2, 425-433. [CrossRef]

159. Schmit, F.; Utermark, T.; Zhang, S.; Wang, Q.; Von, T.; Roberts, T.M.; Zhao, J.J. Pi3k isoform dependence of pten-deficient tumors can be altered by the genetic context. Proc. Natl Acad Sci USA 2014, 111, 6395-6400. [CrossRef]

160. Weigelt, B.; Warne, P.H.; Lambros, M.B.; Reis-Filho, J.S.; Downward, J. Pi3k pathway dependencies in endometrioid endometrial cancer cell lines. Clin. Cancer Res. 2013, 19, 3533-3544. [CrossRef]

161. Berenjeno, I.M.; Guillermet-Guibert, J.; Pearce, W.; Gray, A.; Fleming, S.; Vanhaesebroeck, B. Both p110alpha and p110beta isoforms of pi3k can modulate the impact of loss-of-function of the pten tumour suppressor. Biochem. J. 2012, 442, 151-159. [CrossRef] [PubMed]

162. Wang, D.; Wang, M.; Jiang, N.; Zhang, Y.; Bian, X.; Wang, X.; Roberts, T.M.; Zhao, J.J.; Liu, P.; Cheng, H. Effective use of pi3k inhibitor bkm120 and parp inhibitor olaparib to treat pik3ca mutant ovarian cancer. Oncotarget 2016, 7, 13153-13166. [CrossRef] [PubMed]

163. Wallin, J.J.; Guan, J.; Prior, W.W.; Edgar, K.A.; Kassees, R.; Sampath, D.; Belvin, M.; Friedman, L.S. Nuclear phospho-akt increase predicts synergy of pi3k inhibition and doxorubicin in breast and ovarian cancer. Sci. Transl. Med. 2010, 2, 48ra66. [CrossRef] [PubMed]

164. Thomadaki, H.; Scorilas, A.; Tsiapalis, C.M.; Havredaki, M. The role of cordycepin in cancer treatment via induction or inhibition of apoptosis: Implication of polyadenylation in a cell type specific manner. Cancer Chemother Pharm. 2008, 61, 251-265. [CrossRef] [PubMed]

165. Cui, Z.Y.; Park, S.J.; Jo, E.; Hwang, I.H.; Lee, K.B.; Kim, S.W.; Kim, D.J.; Joo, J.C.; Hong, S.H.; Lee, M.G.; et al. Cordycepin induces apoptosis of human ovarian cancer cells by inhibiting ccl5-mediated akt/nf-kappab signaling pathway. Cell Death Discov. 2018, 4, e62. [CrossRef] [PubMed]

166. Chefetz, I.; Holmberg, J.C.; Alvero, A.B.; Visintin, I.; Mor, G. Inhibition of aurora-a kinase induces cell cycle arrest in epithelial ovarian cancer stem cells by affecting nfkb pathway. Cell Cycle 2011, 10, 2206-2214. [CrossRef] [PubMed]

167. Thakur, B.; Ray, P. Cisplatin triggers cancer stem cell enrichment in platinum-resistant cells through nf-kappab-tnfalpha-pik3ca loop. J. Exp. Clin. Cancer Res. 2017, 36, e164. [CrossRef] [PubMed]

168. Gonzalez-Torres, C.; Gaytan-Cervantes, J.; Vazquez-Santillan, K.; Mandujano-Tinoco, E.A.; Ceballos-Cancino, G.; Garcia-Venzor, A.; Zampedri, C.; Sanchez-Maldonado, P.; Mojica-Espinosa, R.; Jimenez-Hernandez, L.E.; et al. Nf-kappab participates in the stem cell phenotype of ovarian cancer cells. Arch. Med. Res. 2017, 48, 343-351. [CrossRef]

169. House, C.D.; Jordan, E.; Hernandez, L.; Ozaki, M.; James, J.M.; Kim, M.; Kruhlak, M.J.; Batchelor, E.; Elloumi, F.; Cam, M.C.; et al. Nfkappab promotes ovarian tumorigenesis via classical pathways that support proliferative cancer cells and alternative pathways that support aldh $(+)$ cancer stem-like cells. Cancer Res. 2017, 77, 6927-6940. [CrossRef]

170. Tang, S.; Xiang, T.; Huang, S.; Zhou, J.; Wang, Z.; Xie, R.; Long, H.; Zhu, B. Ovarian cancer stem-like cells differentiate into endothelial cells and participate in tumor angiogenesis through autocrine ccl5 signaling. Cancer Lett. 2016, 376, 137-147. [CrossRef]

171. Jin, Z.; Niu, H.; Wang, X.; Zhang, L.; Wang, Q.; Yang, A. Preclinical study of cc223 as a potential anti-ovarian cancer agent. Oncotarget 2017, 8, 58469-58479. [CrossRef] [PubMed]

172. Shida, D.; Takabe, K.; Kapitonov, D.; Milstien, S.; Spiegel, S. Targeting sphk1 as a new strategy against cancer. Curr. Drug Targets 2008, 9, 662-673. [CrossRef] [PubMed]

173. Vadas, M.; Xia, P.; McCaughan, G.; Gamble, J. The role of sphingosine kinase 1 in cancer: Oncogene or non-oncogene addiction? Biochim. Biophys. Acta 2008, 1781, 442-447. [CrossRef] [PubMed]

174. Choi, H.J.; Heo, J.H.; Park, J.Y.; Jeong, J.Y.; Cho, H.J.; Park, K.S.; Kim, S.H.; Moon, Y.W.; Kim, J.S.; An, H.J. A novel pi3k/mtor dual inhibitor, cmg002, overcomes the chemoresistance in ovarian cancer. Gynecol. Oncol. 2019, 153, 135-148. [CrossRef] [PubMed]

175. Speranza, M.C.; Nowicki, M.O.; Behera, P.; Cho, C.F.; Chiocca, E.A.; Lawler, S.E. Bkm-120 (buparlisib): A phosphatidyl-inositol-3 kinase inhibitor with anti-invasive properties in glioblastoma. Sci. Rep. 2016, 6, e20189. [CrossRef] [PubMed] 
176. Juric, D.; Rodon, J.; Tabernero, J.; Janku, F.; Burris, H.A.; Schellens, J.H.M.; Middleton, M.R.; Berlin, J.; Schuler, M.; Gil-Martin, M.; et al. Phosphatidylinositol 3-kinase alpha-selective inhibition with alpelisib (byl719) in pik3ca-altered solid tumors: Results from the first-in-human study. J. Clin. Oncol. 2018, 36, 1291-1299. [CrossRef] [PubMed]

177. Bendell, J.C.; Javle, M.; Bekaii-Saab, T.S.; Finn, R.S.; Wainberg, Z.A.; Laheru, D.A.; Weekes, C.D.; Tan, B.R.; Khan, G.N.; Zalupski, M.M.; et al. A phase 1 dose-escalation and expansion study of binimetinib (mek162), a potent and selective oral mek1/2 inhibitor. Br. J. Cancer 2017, 116, 575-583. [CrossRef]

178. Mensah, F.A.; Blaize, J.P.; Bryan, L.J. Spotlight on copanlisib and its potential in the treatment of relapsed/refractory follicular lymphoma: Evidence to date. Onco. Targets 2018, 11, 4817-4827. [CrossRef]

179. Sun, K.; Atoyan, R.; Borek, M.A.; Dellarocca, S.; Samson, M.E.; Ma, A.W.; Xu, G.X.; Patterson, T.; Tuck, D.P.; Viner, J.L.; et al. Dual hdac and pi3k inhibitor cudc-907 downregulates myc and suppresses growth of myc-dependent cancers. Mol. Cancer 2017, 16, 285-299. [CrossRef]

180. Caro-Vegas, C.; Bailey, A.; Bigi, R.; Damania, B.; Dittmer, D.P. Targeting mtor with mln0128 overcomes rapamycin and chemoresistant primary effusion lymphoma. MBio 2019, 10, e02871-18. [CrossRef]

181. Richardson, P.G.; Eng, C.; Kolesar, J.; Hideshima, T.; Anderson, K.C. Perifosine, an oral, anti-cancer agent and inhibitor of the akt pathway: Mechanistic actions, pharmacodynamics, pharmacokinetics, and clinical activity. Expert Opin. Drug Metab. Toxicol. 2012, 8, 623-633. [CrossRef]

182. Chen, W.C.; Lai, Y.A.; Lin, Y.C.; Ma, J.W.; Huang, L.F.; Yang, N.S.; Ho, C.T.; Kuo, S.C.; Way, T.D. Curcumin suppresses doxorubicin-induced epithelial-mesenchymal transition via the inhibition of tgf-beta and pi3k/akt signaling pathways in triple-negative breast cancer cells. J. Agric. Food Chem. 2013, 61, 11817-11824. [CrossRef] [PubMed]

183. Choi, B.H.; Kim, C.G.; Lim, Y.; Shin, S.Y.; Lee, Y.H. Curcumin down-regulates the multidrug-resistance mdr1b gene by inhibiting the pi3k/akt/nf kappa b pathway. Cancer Lett. 2008, 259, 111-118. [CrossRef] [PubMed]

184. Sesarman, A.; Tefas, L.; Sylvester, B.; Licarete, E.; Rauca, V.; Luput, L.; Patras, L.; Banciu, M.; Porfire, A. Anti-angiogenic and anti-inflammatory effects of long-circulating liposomes co-encapsulating curcumin and doxorubicin on c26 murine colon cancer cells. Pharmacol. Rep. Pr. 2018, 70, 331-339. [CrossRef] [PubMed]

185. Sesarman, A.; Tefas, L.; Sylvester, B.; Licarete, E.; Rauca, V.; Luput, L.; Patras, L.; Porav, S.; Banciu, M.; Porfire, A. Co-delivery of curcumin and doxorubicin in pegylated liposomes favored the antineoplastic c26 murine colon carcinoma microenvironment. Drug Deliv. Transl. Res. 2019, 9, 260-272. [CrossRef] [PubMed]

186. Kaklamani, V.G.; Richardson, A.L.; Arteaga, C.L. Exploring biomarkers of phosphoinositide 3-kinase pathway activation in the treatment of hormone receptor positive, human epidermal growth receptor 2 negative advanced breast cancer. Oncologist 2019, 24, 305-312. [CrossRef] [PubMed]

187. Todoric, J.; Antonucci, L.; Karin, M. Targeting inflammation in cancer prevention and therapy. Cancer Prev. Res. 2016, 9, 895-905. [CrossRef] [PubMed]

(C) 2019 by the authors. Licensee MDPI, Basel, Switzerland. This article is an open access article distributed under the terms and conditions of the Creative Commons Attribution (CC BY) license (http://creativecommons.org/licenses/by/4.0/). 